\title{
Nephroprotective Effect of Aqueous extract of Solanum Nigrum LINN LEAVES OR SEEDS AND THEIR MIXTURE AGAINST GENTAMICIN- INDUGED NEPHROTOXICITY IN RATS
}

\author{
By \\ Maysa M. El Mallah \\ Nutrition and Food Sciences \\ Department, Faculty of Home \\ Economics, Helwan University \\ Reham S. Ramadan \\ Nutrition and Food Sciences \\ Department, Faculty of Home \\ Economics, Helwan University
}

Research Gournal Specific Fducation

Faculty of Specific Fducation

glansoura University

ISSUE NO. 43, JULY. 2016

$$
\text { مجلة بحوث التربية النوعية - جامعة المنصورة }
$$




\title{
Nephroprotective Effect of Aqueous Extract of Solanum Nigrum LINN LEAVES OR SEEDS AND THEIR MIXTURE AGAINST GENTAMICIN- INDUCED NEPHROTOXICITY IN RATS
}

\author{
Maysa M. El Mallah* \\ Reham S. Ramadan
}

\section{Abstract}

The present study aimed to elucidate the nephroprotective effect of different doses of aqueous extract of Solanum Nigrum Linn (AE-SN)leaves or seeds and their mixture against gentamicin-induced nephrotoxicity in rats. Forty eight mature male rats weighted $(160 \pm 5 \mathrm{~g})$ were randomly divided into eight groups 6 rats each. Group (1) rats were fed on basal diet and served as a negative control, while the other 7 groups were intoxicated by a single intraperioneal dose $(100 \mathrm{mg} / \mathrm{kg})$ of gentamicin to rats at the 4 th week; once daily for end of the experiment (4 weeks) for induction of nephrotoxicity. Group (2) was kept intoxicated ( a positive control group ) while groups 3, 4, 5 and 6 were pre- treated orally with AE-SN extract of leaves and seeds in a dose of 250 and $500 \mathrm{mg} / \mathrm{kg}$ b.wt., respectively for 4 weeks. Groups 7 and 8 were pre- treated orally with a mixture of aqueous extract of Solanum Nigrum Linn leaves and seeds in a dose of 250 and $500 \mathrm{mg} / \mathrm{kg}$ b.wt respectively for 4 weeks.Feed intake was calculated daily and body weight gain was recorded weekly. Blood samples were collected and kidneys were weighted, dissected out and taken for biochemical analyses and histopathological study. Pre- treatment with AE-SN extract of leaves or seed and their mixture improved feed intake and increased body weight gain and normalized kidney weight compared to GM intoxicated rats. Also AE-SN significantly improved levels of renalmarkers and maintaining the electrolyte balance by decreasing serum level of some mineral element ( $\mathrm{Na}, \mathrm{K}$ and $\mathrm{P}$ ), and increase level of calcium and vit. $\mathrm{D}$. in serum compared to negative control group. Improved renal function by AESN treatment caused an increase in Renin, Erythropoietin (EPO) and

\footnotetext{
Nutrition and Food Sciences Department, Faculty of Home Economics, Helwan University
} 
parathyroid hormones. There were also an increase in renal antioxidant enzyme activity and partial amelioration of renal degeneration. In conclusion AE-SN aqueous extract of leave was more effective than aqueous extract of seeds. Pre-treatment with AE-SN mixture at high doses, significantly normalized level of renal markers and antioxidant activities. Ameliorative effects of AE-SN leaves or seeds and their mixture against gentamicin induced nephrotoxicity may be attributed to their antioxidant properties.

Key words: nephrotoxicity, SolanumNigrumLinn gentamicin \& rat.

\section{Introduction}

Nephrotoxic injury is damage to one or both of the kidneys and results from exposure to a toxic material that can occur in many different ways, depending upon the type of agent. Toxin has direct effect on the glomerulus or the renal tubules and leads to destruction of cells (Barbier etal., 2005). Most drugs are found to cause nephrotoxicity or toxic effects that include altered inflammation, tubular cell toxicity, intra-glomerular hemodynamic, crystal nephropathy, thrombotic microangiopathy rhabdomyolysis (Mondi etal., 2014) and (Grases etal., 2015) .

Gentamicin (GM) is amino glycoside antibiotics have long been employed as antibacterial remedy, particularly against gram negative bacterial infections Ali et al., (2005). Gentamicin is known as nephrotoxic agent. It damages the tubular cells lacking morphological changes in glomerulus structures (Ziets et al., 2009) .

Many herbs have been proven to be effectual as nephroprotective agents while many more are claimed to be nephroprotective Lakashmi etal., (2012).

Solanumnigrum Linn (family: Solanaceae) commonly known as black nightshade, grows as a weed, found in the dry parts of India and other parts of the world. It has a long history of medicinal usage and has been used as a traditional folk medicine for treating various ailments such as pain, inflammation, fever and liver disorders Gogoi and islam (2012 ). Generally, black nightshade is very rich in nutritive values, which are capable of supplying minerals, vitamins, proteins, and certain hormone precursors 
(Arulmozhi etal., 2012). This herb elaborates a wide spectrum of medicinal properties such as anticancer, diuretic, antioxidant, antiulcer antimicrobial, nephroprotective (Al-Qirim et al.,2008), (Arulmozhi etal., 2010), ((Singh etal., 2011) and (Harika etal., 2013 ) .

A recent report has shown that Solanum nigrum exerts protection against liver fibrosis (Hsieh etal.,2008). Several photochemicals have been identified and isolated from Solanum nigrum, which contain alkaloids, flavonoids, saponins, tannins, phytic acid and hydrocyanic acid, steroidal glycosides (Potawel etal.,2008). Leaves were found to be richer in polyphenols than stem and fruit (Hsiu-Chen et al.,,2010) . Solanumnigrum leaves contained the highest concentration of gentisic acid, luteolin, apigenin, kaempferol, and macoumaric acid(Atanu et.al., 2011).

Therefore, the present study is carried out to elucidate nephroprotective effect of aqueous extract of (S. nigrum) leaves or seeds and their mixture with different doses against gentamicin-induced renal toxicity in male rats .

\section{Materials and Methods}

\section{A. Materials:}

\section{Natural Plant leaves and seeds :}

Dried leaves and seeds of Solanum nigrum L.(family: Solanaceae were obtained from the market of Ministry of Agriculture in Cairo city, Egypt. Seeds and leaves were ground separately into a fine powder using a coffee mixer and stored in an air-tight contained, kept in a desiccators until analyzed and preparation.

Gentamicin is an amino glycoside antibiotic was purchased from El-Gomhoria Co., Egypt city,. Gentamicin is given to rats in dose a 100 $\mathrm{mg} / \mathrm{kg} /$ day for 7 days intraperitoneal for inducing renal damage according to previous studies as reported by Farombi and Ekor (2006).

\section{Chemicals and kits :}

Kits for biochemical analysis were purchased from the gamma trade company for pharmaceutical and chemicals, Dokki,Egypt. And chemicals were purchased from EL - Gomhorya company Cairo ,city ,Egypt . 
- Nephroprotective Effect of Aqueous Extract of Solanum Nigrum Linn leaves or seeds

\section{Experimental animals}

Forty eight mature male albino rats of Sprague Dawley strain weighing $(160 \pm 5 \mathrm{~g})$ and 10-12 weeks old were purchased from Laboratory of Animal Colony Helwan Egypt.

\section{B. B.Methods:-}

\section{Chemical analyses of Solanumnigrum $L$ :}

Moisture, protein, fat, ash, mineral elements $(\mathrm{Ca}, \mathrm{Na}, \mathrm{K}, \mathrm{P})$ and vitamin C of Solanum nigrum L (leaves and seeds) fine powder were determined separately according to the methods of the (A.O.A.C. 2000), while total carbohydrates were calculated by differences as following :

Carbohydrate $\%=100$ - (Moisture $\%+$ protein $\%+$ fat $\%+$ Ash $\%$ ).

\section{Determination of the total phenolic compounds and total flavonoid of Solanumnigrum $L$ :}

Total phenolic concentration was analyzed using the method described by singleton $\boldsymbol{e t}$ al., (1965).Total flavonoid concentration was quantified using the spec- trophotometric method described by Jia $\boldsymbol{e t}$ al., (1999).

\section{Preparation of the basal diet:}

Basal diet was prepared according to Reeves et al., (1993). It consists of $20 \%$ protein (casein), $10 \%$ sucrose, $4 \%$ corn oil, $0.2 \%$ chlorine chloride, $1 \%$ vitamin mixture, $3.5 \%$ salt mixture , $5 \%$ fibers (cellulose) and the remainder was corn starch up to $100 \%$.

4. Preparation of aqueous extract of Solanum nigrum L leaves and seeds

Fine powder of Solanumnigrum $L$ leaves and seeds at $100 \mathrm{gm}$ were suspended separately in $250 \mathrm{ml}$ of water for 2 hours and then heated at 60$65^{\circ} \mathrm{C}$ for $30 \mathrm{~min}$. The extract was collected separately and the processes were repeated 3 times with the residual powder, each time collecting the extract. The collected extracts were pooled and passed through fine cotton cloth. The filtrates were evaporated at $40-50^{\circ} \mathrm{C}$ in a rotavapour under reduced pressure. A dark semisolid material (yield-14\%) obtained was 
stored at $0-4^{\circ} \mathrm{C}$ until use Arulmozhi et al., 2012. A known amount of the residual extracts were suspended in distilled water and was orally administered to rats .

\section{Induction of nephrotoxicity.}

Gentamicin was given intraperitoneal injections to rats at a dose of $100 \mathrm{mg} / \mathrm{kg} \mathrm{b} . \mathrm{wt}$ at the 4 th week daily till the end of the experiment for induction of nephrotoxicity according to Farombi and Ekor (2006).

\section{Experimental Design :}

Rats were maintained under controlled hygienic conditions. Animals were fed on basal diet and water was provided ad libitum. Rats were allowed to acclimatize to the laboratory environment for 7 days before starting of the experiment. The experiment was performed on forty eight adult Sprague Dawley rats weighted $(160 \pm 5 \mathrm{~g})$ randomly distributed into 8 groups, of 6 rats each. Group 1 was kept as a normal (negative) control group, received a single intraperitoneal (i.p.) injection of normal saline $(2.5 \mathrm{ml} / \mathrm{kg})$, while the other 7 groups were intoxicated by intraperitoneal dose $(100 \mathrm{mg} / \mathrm{kg})$ of gentamicin injected to rats in the $4^{\text {th }}$ week, once daily till the end of the experiment (4 weeks) for induction of nephrotoxicity which classified into control positive group and and groups 3, 4, 5 and 6 were pre- treated orally with (AE-SN) of leave and seeds in a dose of 250 and $500 \mathrm{mg} / \mathrm{kg}$ b.wt .,respectively. While Groups 7 and 8 were pre- treated orally with a mixture (AE-SN) of leave and seeds in a dose of 250 and $500 \mathrm{mg} / \mathrm{kg}$ b.wt . Food and water was provided ad-libtum. Feed intake was recorded daily and body weight of rats was measured once weekly. At the end of the experimental period (four weeks) The rats were euthanized by prolonged exposure to ether and blood samples were withdrawn for separating the serum by centrifugation at $8000 \mathrm{rpm}$ for $15 \mathrm{~min}$. Serum samples were kept frozen at $-70 \dot{C}$ till biochemical analyses. A part of the kidney was kept frozen until used for preparing tissue homogenates for biochemical analyses. The other part was preserved in $10 \%$ formalin solution till processed for the histopathological examination of kidney . 
- Nephroprotective Effect of Aqueous Extract of Solanum Nigrum Linn leaves or seeds

\section{Kidney function marker:}

Blood urea nitrogen was determined using Bio Mérieux kits according to (Patton and Crouch 1977), Serum uric acid was determined using the enzymatic colorimetric method as described by (Fossati et al., 1980). Serum creatinine concentrations were calorimetrically determined by( Husdan and Rapoport , 1968). Serum total protein and albumin were determined as described by the method of (Weichselbaum 1946) and (Bartholomev and Deleny 1966). Estimation of some serum minerals ( $\mathrm{Na}$ $, \mathrm{K}, \mathrm{p}, \mathrm{Ca}$ ) were according to pupsa et al ., (1994) . Renin and erythropoietin (EPO) were estimated according to ( Van - kats et al .,2001) - Vitamin D was determined according to (vale rie et al ., 2006) .

\section{Preparation of kidney Homogenate:}

One gram of frozen kidney tissue was taken, washed with ice-cooled $0.9 \% \mathrm{NaCl}$ solution and homogenized in ice-cooled $100 \mathrm{ml}$ of $1.5 \%$ solution of potassium chloride and $50 \mathrm{mM}$ potassium phosphate buffer solution $(\mathrm{pH}$ 7.4) to yield $1 \%$ homogenate (W/V). Homogenates were centrifuged at 4000 rpm at $4^{\circ} \mathrm{C}$ for 15 minutes and the supernatants were collected for biochemical analyses. Khundmiri et al.,(2004).

\section{Estimation of kidney antioxidant enzymes}

Lipid per oxidation (LPO) was determined by measuring malondialdehyde (MDA) (Marker of lipid per oxidation) that formed in terms of thiobarbituric acid reactive substances (TBARS). Kidney homogenates were used for determination of tissue lipid peroxide, malondialdehyde (MDA) and enzymatic (GPx, SOD and CAT) and non enzymatic (reduced glutathione, GSH) antioxidants. Tissue GSH content in kidney homogenate was calorimetrically determined by the modified method of Afzal et al. (2002). Malondialdehyde (MDA) content was determined according to Ohkawa et al. (1979). Activities of glutathione peroxides (GPx), superoxide dismutase (SOD) and catalase (CAT) antioxidant enzymes were chemically determined according to Paglia and Valentaine (1979), Spitz and Oberley (1989) and Sinha (1972), respectively 


\section{Histopathological examination:-}

The fixed samples of kidney in $10 \%$ neutral buffered formalin were cleared in xylol and embeded in paraffin 4-5 $\mu \mathrm{m}$ thick section and stained with Hematoxylin and Eosin (H\&E) for subsequent histopathological examination according to Carleton,(1979).

\section{Statistical analysis:}

Statistical analysis was carried out using Statistical Package for the Social Sciences (SPSS) for Windows, version 20 (SPSS Inc., Chicago, IL, USA). Collected data was presented as mean \pm standard deviation (SD). Analysis of Variance (ANOVA) test was used for determining the significances among different groups according to Armitage et al. (2002). All differences were consider significant if $\mathrm{P} \cdot 0.05$.

\section{Results}

Proximate composition of leaves and seeds of solanum nigrum $\mathrm{L}$. was presented in (Table 1). Ash, protein, fiber and moisture contents are higher in the leaves compared to the seeds, while total fat and carbohydrate was higher in seed than leaves.

Table 1 : Gross chemical composition of Solanum Nigrum L. leaves and seeds $(\mathrm{mg} / 100 \mathrm{~g})$

\begin{tabular}{||c|c|c||}
\hline Parameters $\%$ & Dry matter of leave & Dry matter of seed \\
\hline \hline Ash content & 10.18 & 8.05 \\
\hline Total fat & 4.60 & 12.18 \\
\hline Total protein & 24.90 & 17.63 \\
\hline Total carbohydrate & 53.51 & 55.85 \\
\hline Total fiber & 6.81 & 6.29 \\
\hline Total moisture & 84.70 & 76.86 \\
\hline
\end{tabular}

Elemental Composition of SolanumnigrumL.Leaves and seeds was shown in (Table 2), indicated that $S$. nigrum contains high levels of $\mathrm{Mg}, \mathrm{p}$ $, \mathrm{k}, \mathrm{ca}$ and $\mathrm{Fe}$ and $\mathrm{Na}$ in leaves than seeds.. The order of these element is magnesium, phosphor, potassium, Calcium, iron and sodium . On the other 
hand S. nigrum contains high levels of vitamin C and Vitamin E. The concentration of these vitamin ( $\mathrm{C}$ and $\mathrm{E})$ was higher in leaves than seeds.

Table 2 : Some mineral and Vitamin content of Solanum nigrum L. Leaves and seeds $(\mathrm{mg} / 100 \mathrm{~g})$

\begin{tabular}{||c|c|c||}
\hline .Parameters & $\begin{array}{c}\text { Composition } \\
(\mathrm{mg} / 100 \mathrm{~g}) \text { of Leaves }\end{array}$ & $\begin{array}{c}\text { Composition } \\
(\mathrm{mg} / 100 \mathrm{~g}) \text { of seeds }\end{array}$ \\
\hline \hline Sodium $\mathrm{Na}$ & 2.71 & 2.1 \\
\hline Potassium $\mathrm{K}$ & 42.89 & 37.17 \\
\hline Calcium $\mathrm{Ca}$ & 17.33 & 11.82 \\
\hline Phosphor $\mathrm{p}$ & 75.22 & 62.50 \\
\hline Magnesium $\mathrm{Mg}$ & 247.59 & 201.36 \\
\hline Iron $\mathrm{Fe}$ & 13.01 & 12.91 \\
\hline Vitamin $\mathrm{C}$ & 35.18 & 23.38 \\
\hline Vitamin $\mathrm{E}$ & 9.72 & 5.71 \\
\hline
\end{tabular}

Data recorded in Table (3) showed that, total Polyphenol and flavonoid levels were high in both leaves and seed of S. nigrum but the highest levels were in leaves.

Table 3: Total phenolic and total flavonoid compounds content in the extracts of Solanum nigrum L. leaves and seeds $(\mathrm{mg} / 100 \mathrm{~g})$

\begin{tabular}{|c|c|c|}
\hline \hline Parameter & $\begin{array}{c}\text { Composition } \\
(\mathrm{mg} / 100 \mathrm{~g}) \text { of Leaves }\end{array}$ & $\begin{array}{c}\text { Composition } \\
(\mathrm{mg} / 100 \mathrm{~g}) \text { of seeds }\end{array}$ \\
\hline \hline T. Polyphenols & 10.27 & 8.24 \\
\hline T. Flavonoids & 1.01 & 0.81 \\
\hline
\end{tabular}

Data in table (4) showed that, injection with GM alone at a dose of $100 \mathrm{mg} / \mathrm{kg}$ b.wt for 7 days caused a significant reduction in both of feed intake and body weight where as the kidney -body weight ratio was found to be increased as compared to control. Pre treated orally with (AE-SN) seeds or leaves and their mixture at 250 and $500 \mathrm{mg} / \mathrm{kg}$ b.wt before concomitant with GM for additional 7 days increased food intake and reversed the weight loss during the experimental period compared to rats treated with 
GM alone. Pr-treated with (AE-SN) leave and seed mixture at dose 250 and $500 \mathrm{mg} / \mathrm{kg}$ b.wt caus ed the highest increase in feed intake $(17.20 \mathrm{~g})$ and $(17.00 \mathrm{~g})$ respectively compared to control positive group $(15.56 \mathrm{~g})$. The highest increase in feed intake due to the highest increase in weight gain ratio in the same group as $(24.11 \pm 1.02 \%)$ and $(30.41 \pm 1.01 \%)$ respectively. Also the same treatment caused increase in relative kidney weight in the same groups as $(1.68 \pm 0.11 \%)$ and $(1.79 \pm 0.63 \%)$ compared to control positive group $(1.58 \pm 0.43 \%)$.

Table 4: Effect of AE-SN leaves or seeds and their mixture on body weight gain, feed intake and relative kidney weight in nephrotoxic rats.

\begin{tabular}{|c|c|c|c|c|c|c|c|}
\hline \multicolumn{3}{|c|}{ Groups Parameters } & $\begin{array}{l}\text { Initial weight } \\
(\mathrm{g})\end{array}$ & $\begin{array}{c}\text { Final weight } \\
(\mathrm{g})\end{array}$ & $\begin{array}{l}\text { Bodyweight } \\
\text { gain \% }\end{array}$ & $\mathrm{FI}(\mathrm{g})$ & $\begin{array}{c}\text { Relative } \\
\text { kidney weight } \%\end{array}$ \\
\hline \multicolumn{3}{|c|}{$\begin{array}{c}\text { G 1: } \\
\text { Control -ve }\end{array}$} & $171.67 \pm 1.52 \mathrm{a}$ & $250.14 \pm 1.64 a$ & $45.70 \pm 1.07 \mathrm{a}$ & $19.30 \pm 1.32 \mathrm{a}$ & $1.88 \pm 0.44 \mathrm{a}$ \\
\hline \multirow{7}{*}{ 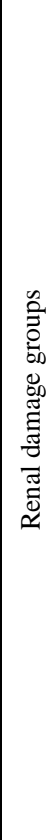 } & \multicolumn{2}{|r|}{$\begin{array}{c}\text { G 2: } \\
\text { Control + ve }\end{array}$} & $175.00 \pm 1.64 \mathrm{a}$ & $205.13 \pm 1.72 \mathrm{c}$ & $17.21 \pm 1.08 \mathrm{c}$ & $15.56 \pm 1.19 \mathrm{c}$ & $1.58 \pm 0.43 \mathrm{~d}$ \\
\hline & \multirow{6}{*}{ 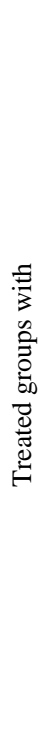 } & $\begin{array}{c}\text { G3: } \\
\text { AE-SN leave } \\
\text { extract } 250 \mathrm{mg}\end{array}$ & $173.55 \pm 1.02 \mathrm{a}$ & $210.22 \pm 1.13 \mathrm{c}$ & $21.13 \pm 1.04 \mathrm{c}$ & $16.87 \pm 1.08 \mathrm{~b}$ & $1.63 \pm 0.11 \mathrm{c}$ \\
\hline & & $\begin{array}{c}\text { G4: } \\
\text { AE-SN seed extract } \\
250 \mathrm{mg} \\
\end{array}$ & $172.43 \pm 1.13 \mathrm{a}$ & $215.12 \pm 1.16 b$ & $24.75 \pm 1.03 b$ & $16.00 \pm 1.42 b$ & $1.71 \pm 0.21 b$ \\
\hline & & $\begin{array}{c}\text { G5: } \\
\text { AE-SN leave } \\
\text { extract 500mg }\end{array}$ & $173.80 \pm 1.10 \mathrm{a}$ & $217.12 \pm 1.11 \mathrm{~b}$ & $24.93 \pm 1.01 b$ & $16.99 \pm 1.15 b$ & $1.69 \pm 0.23 \mathrm{c}$ \\
\hline & & $\begin{array}{c}\text { G6 } \\
\text { AE-SN seed extract } \\
500 \mathrm{mg}\end{array}$ & $174.30 \pm 1.20 \mathrm{a}$ & $219.43 \pm 1.21 b$ & $25.89 \pm 1.01 \mathrm{~b}$ & $17.29 \pm 1.28 b$ & $1.74 \pm 0.71 b$ \\
\hline & & $\begin{array}{c}\text { G7: } \\
\text { AE-SN mixture } \\
250 \mathrm{mg} \\
\end{array}$ & $174.30 \pm 1.22 \mathrm{a}$ & $216.32 \pm 1.42 b$ & $24.11 \pm 1.02 b$ & $17.20 \pm 1.27 \mathrm{~b}$ & $1.68 \pm 0.11 \mathrm{c}$ \\
\hline & & $\begin{array}{c}\text { G8: } \\
\text { AE-SN mixture } \\
500 \mathrm{mg}\end{array}$ & $174.30 \pm 1.11 \mathrm{a}$ & $227.31 \pm 1.12 b$ & $30.41 \pm 1.01 \mathrm{~b}$ & $17.00 \pm 1.24 \mathrm{~b}$ & $1.79 \pm 0.63 b$ \\
\hline
\end{tabular}

Mean \pm SD values in each raw with different superscripts $(a, b, c, d)$ are significantly different as compared to the control groups at $P<0.05 \mathrm{n}=6$ rats/group. 
Results in Table (5) showed the effect of (AE-SN) seeds or leaves and their mixture on renal functional markers. Rats given (GM) intraperitoneal alone at a dose of $100 \mathrm{mg} / \mathrm{kg}$ b.wt for 7 days, resulting in a significant increase in serum urea nitrogen, uric acid and creatinine concentration compared to control negative group. These elevations in blood urea, uric acid and creatinine concentrations were significantly $(\mathrm{P}<0.05)$ attenuated by all the pre treated with (AE-SN) seeds or leaves and their mixture at 250 and $500 \mathrm{mg} / \mathrm{kg}$ b.wt, indicating their nephroprotective activities. Group-5 and group- 8 exhibited more positive nephroprotective effects, having significantly $(\mathrm{P}<0.05)$ lower values of urea nitrogen, uric acid and creatinine level when compared to normal values. However, group8 had the numerically lowest value of serum urea nitrogen, uric acid and creatinine levels as compared to control negative group, indicating their improved nephroprotective activity

Table 5 : Effect of AE-SN leaves or seeds and their mixture on serum urea nitrogen, uric acid and creatinine concentrations in nephrotoxic rats .

\begin{tabular}{|c|c|c|c|c|c|}
\hline \multicolumn{3}{|c|}{\begin{tabular}{|ll} 
Groups & Parameters \\
\end{tabular}} & $\begin{array}{l}\text { Urea nitrogen } \\
(\mathrm{mg} / \mathrm{dl})\end{array}$ & $\begin{array}{r}\text { uric acid } \\
(\mathrm{mg} / \mathrm{dl})\end{array}$ & $\begin{array}{l}\text { creatinine } \\
(\mathrm{mg} / \mathrm{dl})\end{array}$ \\
\hline \multicolumn{3}{|r|}{ G 1: Control - ve } & $27.65 \pm 1.32 d$ & $2.77 \pm 0.02 \mathrm{~d}$ & $0.5 \pm 0.15 d$ \\
\hline \multirow{7}{*}{ 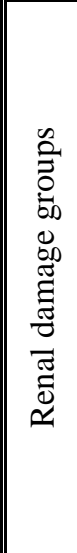 } & \multirow{6}{*}{ 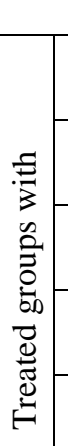 } & G 2: Control + ve & $72.16 \pm 1.93 a$ & $5.87 \pm 0.05 a$ & $3.5 \pm 0.17 \mathrm{a}$ \\
\hline & & $\begin{array}{c}\text { G3: AE-SN leave extract } \\
\text { 250mg/kgb.wt }\end{array}$ & $65.14 \pm 5.13 b$ & $4.22 \pm 0.43 b$ & $2.0 \pm 0.56 \mathrm{~b}$ \\
\hline & & $\begin{array}{c}\text { G4: AE-SN seed extract } \\
250 \mathrm{mg} / \mathrm{kgb} . \mathrm{wt}\end{array}$ & $66.9 \pm 6.62 b$ & $4.65 \pm 0.61 b$ & $2.3 \pm 0.11 b$ \\
\hline & & $\begin{array}{c}\text { G5: AE-SN leave extract } \\
500 \mathrm{mg} / \mathrm{kgb} . \mathrm{wt}\end{array}$ & $35.4 \pm 4.42 \mathrm{c}$ & $3.30 \pm 0.44 c$ & $2.0 \pm 0.56 b$ \\
\hline & & $\begin{array}{c}\text { G6: AE-SN seed extract } \\
500 \mathrm{mg} / \mathrm{kgb} . \mathrm{wt}\end{array}$ & $37.22 \pm 5.15 c$ & $3.51 \pm 0.72 \mathrm{c}$ & $1.5 \pm 0.35 \mathrm{c}$ \\
\hline & & $\begin{array}{l}\text { G7: AE-SN mixture 250mg } \\
\text { /kgb.wt }\end{array}$ & $38.33 \pm 3.34 \mathrm{c}$ & $3.42 \pm 0.32 \mathrm{c}$ & $1.3 \pm 0.12 \mathrm{c}$ \\
\hline & & $\begin{array}{l}\text { G8: AE-SN mixture 500mg / } \\
\text { kgb.wt }\end{array}$ & $30.12 \pm 1.44 \mathrm{c}$ & $3.00 \pm 0.015 \mathrm{c}$ & $0.7 \pm 0.32 \mathrm{~d}$ \\
\hline
\end{tabular}

Mean \pm SD values in each raw with different superscripts $(a, b, c$,$) are significantly$ different as compared to the control groups at $P<0.05 \mathrm{n}=6$ rats/group.

Total protein, Albumin and globulin concentrations were significantly $(\mathrm{P}<0.05)$ lower in GM-treated intra-peritoneal at a dose of 
$100 \mathrm{mg} / \mathrm{kg}$ b.wt for 7 days as compared to normal control group (Table 6). All the treated groups of (AE-SN) leave or seeds and their mixture at 250 or $500 \mathrm{mg} / \mathrm{kg}$ b.wt for 21 days followed by concomitant administration of GM at $(100 \mathrm{mg} / \mathrm{kg}$ b.wt ip) for 7 days significantly reversed the lowered values of total protein, albumin and globulin induced by GM, indicating their positive effects to renal damage. Whereas pre-treated with leave extract alone at 250 or $500 \mathrm{mg} / \mathrm{kg}$ b.wt caused a significant increase of Tp , Alb and Glb than seeds extract alone at 250 or $500 \mathrm{mg} / \mathrm{kgb}$.wt as compared to normal control group However, high dose of (AE-SN) leave and seed mixture at $500 \mathrm{mg} / \mathrm{kg}$ b.wt (group-8) exhibited substantial higher values of TP,Alb,Glb compared to control positive group.

Table (6):Effect of AE-SN leaves, seeds and their mixture on serum levels of total proteins (TP), albumin (Alb) and globulin(Glb) in nephrotoxic rats .

\begin{tabular}{|c|c|c|c|c|c|}
\hline \multicolumn{3}{|c|}{$\begin{array}{ll}\text { Groups } & \text { Parameters } \\
\end{array}$} & $\begin{array}{c}\mathrm{TP} \\
(\mathrm{g} / \mathrm{dl})\end{array}$ & $\begin{array}{c}\text { Alb } \\
(\mathrm{g} / \mathrm{dl})\end{array}$ & $\begin{array}{c}\text { Glb } \\
(\mathrm{g} / \mathrm{dl})\end{array}$ \\
\hline \multicolumn{3}{|r|}{ Control - ve } & $8.05 \pm 0.05 \mathrm{a}$ & $4.52 \pm 0.12 \mathrm{a}$ & $3.53 \pm 0.07 \mathrm{a}$ \\
\hline \multirow{7}{*}{ 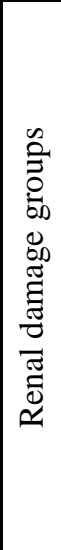 } & & : Control + ve & $4.16 \pm 0.03 c$ & $2.30 \pm 0.14 \mathrm{~b}$ & $1.86 \pm 0.06 \mathrm{c}$ \\
\hline & \multirow{6}{*}{ 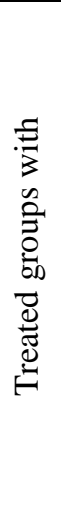 } & $\begin{array}{c}\text { G3: AE-SN leave extract } \\
250 \mathrm{mg} / \mathrm{kgb} . \mathrm{wt}\end{array}$ & $5.2 \pm 0.05 b$ & $2.90 \pm 0.13 b$ & $2.30 \pm 0.04 \mathrm{~b}$ \\
\hline & & $\begin{array}{c}\text { G4: AE-SN seed extract } \\
\text { 250mg/kgb.wt }\end{array}$ & $4.85 \pm 0.04 b$ & $2.70 \pm 0.16 \mathrm{~b}$ & $2.15 \pm 0.01 b$ \\
\hline & & $\begin{array}{c}\text { G5: AE-SN leave extract } \\
\text { 500mg/kgb.wt }\end{array}$ & $6.59 \pm 0.05 \mathrm{a}$ & $3.60 \pm 0.11 \mathrm{a}$ & $2.99 \pm 0.02 \mathrm{a}$ \\
\hline & & $\begin{array}{c}\text { G6: AE-SN seed extract } \\
500 \mathrm{mg} / \mathrm{kgb} . \mathrm{wt} \\
\end{array}$ & $6.11 \pm 0.04 \mathrm{a}$ & $3.20 \pm 0.21 \mathrm{a}$ & $2.91 \pm 0.01 \mathrm{a}$ \\
\hline & & $\begin{array}{l}\text { G7: AE-SN mixture } \\
\text { 250mg/kgb.wt }\end{array}$ & $7.41 \pm 0.01 \mathrm{a}$ & $3.99 \pm 0.15 \mathrm{a}$ & $3.42 \pm 0.01 \mathrm{a}$ \\
\hline & & $\begin{array}{l}\text { G8: AE-SN mixture } \\
500 \mathrm{mg} / \mathrm{kgb} . \mathrm{wt} \\
\end{array}$ & $8.02 \pm 0.03 a$ & $4.51 \pm 0.32 \mathrm{a}$ & $3.51 \pm 0.02 \mathrm{a}$ \\
\hline
\end{tabular}

Mean \pm SD values in each raw with different superscripts $(a, b, c$,$) are significantly$ differentas compared to the control groups at $P<0.05 \mathrm{n}=6$ rats/group.

The statistical data in (table 7) presented that, administration of gentamicin( GM) intra-peritoneal at dose $100 \mathrm{mg} / \mathrm{kg}$ b.wt for 7 days caused a significant increase $(\mathrm{P}<0.05)$ in serum mineral $(\mathrm{Na}, \mathrm{K}$ and $\mathrm{P})$ while caused a significant decrease $(\mathrm{P}<0.05)$ in serum calcium compared with control (ve) group. 
Animal groups treated with oral administration of (AE-SN) leave or seeds and their mixture at 250 or $500 \mathrm{mg} / \mathrm{kg}$ b.wt for 21 days followed by concomitant administration of GM at $(100 \mathrm{mg} / \mathrm{kg}$ b.wt ip) for 7 days showed a significant nephroprotective effect for elevated serum mineral $(\mathrm{Na}, \mathrm{k}$ and $\mathrm{p}$ ) and decreased values of serum calcium level induced by GM treatment .The highest protection was to the rats orally administrated with mixture of leave and seed extract at $(500 \mathrm{mg} / \mathrm{kg}$ b.wt) compared with GM nephrotoxicitygroup (+ve) .

Table (7): Effect of AE-SN leaves or seeds and their mixtureonserum levels of sodium ( Na), potassium (k), Calcium (Ca ) and Phosphorus (P) in nephrotoxic rats.

\begin{tabular}{|c|c|c|c|c|c|c|}
\hline \multicolumn{3}{|c|}{ Groups $\quad$ Parameters } & $\mathrm{Na}(\mathrm{mg} / \mathrm{dl})$ & $\mathrm{K}(\mathrm{mg} / \mathrm{dl})$ & $\mathrm{Ca}(\mathrm{mg} / \mathrm{dl})$ & $\mathrm{P}(\mathrm{mg} / \mathrm{dl})$ \\
\hline \multicolumn{3}{|c|}{ G 1: Control - ve } & $136.50 \pm 0.05 \mathrm{~b}$ & $40.65 \pm 0.53 c$ & $13.40 \pm 0.80 \mathrm{a}$ & $4.18 \pm 0.33 \mathrm{~d}$ \\
\hline \multirow{7}{*}{ 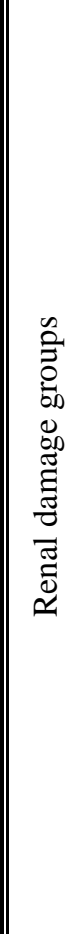 } & \multicolumn{2}{|c|}{ G 2: Control + ve } & $150.33 \pm 0.02 \mathrm{a}$ & $65.48 \pm 0.55 \mathrm{a}$ & $8.48 \pm 0.20 \mathrm{c}$ & $8.60 \pm 0.40 \mathrm{a}$ \\
\hline & \multirow{6}{*}{ 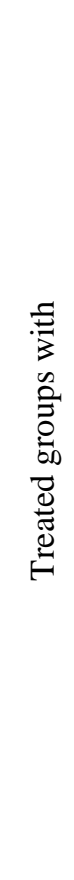 } & $\begin{array}{c}\text { G3: AE-SN } \\
\text { leave extract } \\
\text { 250mg/kgb.wt }\end{array}$ & $145.55 \pm 0.07 \mathrm{a}$ & $55.90 \pm 0.13 b$ & $9.75 \pm 0.04 \mathrm{c}$ & $6.23 \pm 0.69 b$ \\
\hline & & $\begin{array}{c}\text { G4: AE-SN seed } \\
\text { extract } \\
\text { 250mg/kgb.wt }\end{array}$ & $147.42 \pm 0.03 \mathrm{a}$ & $58.27 \pm 0.16 b$ & $9.45 \pm 0.01 \mathrm{c}$ & $6.97 \pm 0.53 b$ \\
\hline & & $\begin{array}{c}\text { G5: AE-SN } \\
\text { leave extract } \\
500 \mathrm{mg} / \mathrm{kgb} . w t\end{array}$ & $140.80 \pm 0.05 b$ & $43.48 \pm 0.43 c$ & $11.54 \pm 0.02 b$ & $5.21 \pm 0.43 \mathrm{c}$ \\
\hline & & $\begin{array}{c}\text { G6: AE-SN seed } \\
\text { extract } \\
500 \mathrm{mg} / \mathrm{kgb} . w t\end{array}$ & $142.30 \pm 0.04 b$ & $45.00 \pm 0.21 \mathrm{c}$ & $10.87 \pm 0.01 b$ & $5.47 \pm 0.49 \mathrm{c}$ \\
\hline & & $\begin{array}{c}\text { G7: AE-SN } \\
\text { mixture } \\
\text { 250mg/kgb.wt }\end{array}$ & $140 . \pm 0.034 \mathrm{~b}$ & $42.34 \pm 0.12 \mathrm{c}$ & $11.99 \pm 0.32 \mathrm{a}$ & $5.11 \pm 0.31 \mathrm{c}$ \\
\hline & & $\begin{array}{l}\text { G8: AE-SN } \\
\text { mixture } \\
500 \mathrm{mg} / \mathrm{kgb} . \mathrm{wt}\end{array}$ & $137.15 \pm 0.08 b$ & $40.51 \pm 0.61 \mathrm{c}$ & $12.45 \pm 0.52 \mathrm{a}$ & $4.84 \pm 0.45 \mathrm{~d}$ \\
\hline
\end{tabular}

Mean \pm SD values in each raw with different superscripts $(a, b, c$,$) are significantly$ differentas compared to the control groups at $P<0.05 n=6$ rats/group. 
Data in table (8) showed that level of renin hormone $(4.68 \pm 0.02$ $\mathrm{ng} / \mathrm{ml} / \mathrm{h})$ and parathyroid hormone $(180.90 \pm 0.02 \mathrm{ng} / \mathrm{ml} / \mathrm{h})$ were significantly increased in the group treated with GM intra-peritoneal at dose of $100 \mathrm{mg} / \mathrm{kg}$ b.wt for 7 days when compared to the value of control (-ve) group $(2.13 \pm 0.05 \mathrm{ng} / \mathrm{ml} / \mathrm{h})(50.40 \pm 0.10 \mathrm{ng} / \mathrm{ml} / \mathrm{h})$ respectively. The same treatment caused a significant decrease in erythropoietin hormone $(1.37 \pm 0.12 \mathrm{ng} / \mathrm{ml} / \mathrm{h})$ and vitamin D $(19.63 \pm 0.32)$ when compared to value of the control (-ve) $(4.564 \pm 0.14 \mathrm{ng} / \mathrm{ml} / \mathrm{h})$ and $(48.45 \pm 0.13)$ respectively. All the pre- treatment with (AE-SN) leave or seeds and their mixture at 250 or $500 \mathrm{mg} / \mathrm{kg} \mathrm{b}$.wt for 21 days followed by concomitant administration of GM at $(100 \mathrm{mg} / \mathrm{kg}$ b.wt ip) for 7 days significantly decreased $(\mathrm{P}<0.05)$ the highest values of renin and parathyroid hormones induced by GM treatment, while the same treatments significantly elevated $(\mathrm{P}<0.05)$ the reduced values of erythropoietin hormone and vitamin $\mathrm{D}$ induced by GM treatment.Pretreatment with leave extract at 250 or $500 \mathrm{mg} / \mathrm{kg}$ b.wt was more effective in reducing level of renin and parathyroid hormone and increasing erythropoietin hormone and vitamin D level than seed extract at the same dose. The mixture of leave and seed extract at $500 \mathrm{mg} / \mathrm{kg} \mathrm{b}$.wt normalized the value of hormones to normal values. 
- Nephroprotective Effect of Aqueous Extract of Solanum Nigrum Linn leaves or seeds

Table (8): Effect of AE-SN leaves or seeds and their mixtureon serum renin erythropoietin and parathyroid hormones and vitamin D in nephrotoxic rats.

\begin{tabular}{|c|c|c|c|c|c|c|}
\hline \multicolumn{3}{|c|}{ Groups } & $\begin{array}{c}\text { Renin } \\
(\mathrm{ng} / \mathrm{ml} / \mathrm{h})\end{array}$ & $\begin{array}{c}\text { EPO } \\
\text { (ng/ml/h) }\end{array}$ & PTH (ng/ml /h) & $\begin{array}{c}\text { VIT. D } \\
\text { (nmol/L) }\end{array}$ \\
\hline \multicolumn{3}{|c|}{ G 1: Control - ve } & $2.13 \pm 0.05 \mathrm{c}$ & $4.56 \pm 0.14 \mathrm{a}$ & $50.40 \pm 0.10 \mathrm{~d}$ & $48.4 \pm 0.13 a$ \\
\hline \multirow{7}{*}{ 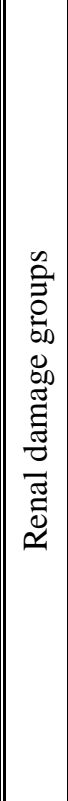 } & & 2: Control + ve & $4.68 \pm 0.02 \mathrm{a}$ & $1.37 \pm 0.12 \mathrm{~d}$ & $180.90 \pm 0.02 \mathrm{a}$ & $19.6 \pm 0.32 d$ \\
\hline & \multirow{6}{*}{ 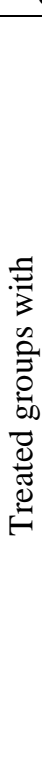 } & $\begin{array}{c}\text { G3: AE-SN leave } \\
\text { extract } \\
\text { 250mg/kgb.wt }\end{array}$ & $3.25 \pm 0.07 \mathrm{~b}$ & $2.56 \pm 0.13 c$ & $130.30 \pm 0.04 b$ & $30.3 \pm 0.14 c$ \\
\hline & & $\begin{array}{c}\text { G4: AE-SN seed } \\
\text { extract } \\
\text { 250mg/kgb.wt }\end{array}$ & $3.80 \pm 0.03 b$ & $1.99 \pm 0.16 \mathrm{~d}$ & $170.7 \pm 0.01 \mathrm{ba}$ & $28.4 \pm 0.52 d$ \\
\hline & & $\begin{array}{c}\text { G5: AE-SN leave } \\
\text { extract } \\
\text { 500mg/kgb.wt }\end{array}$ & $3.25 \pm 0.05 b$ & $2.89 \pm 0.11 \mathrm{c}$ & $90.00 \pm 0.02 \mathrm{c}$ & $38.1 \pm 0.13 c$ \\
\hline & & $\begin{array}{c}\text { G6: } \mathrm{AE}-\mathrm{SN} \text { seed } \\
\text { extract } \\
\text { 500mg/kgb.wt }\end{array}$ & $3.85 \pm 0.04 b$ & $2.00 \pm 0.21 \mathrm{c}$ & $100.30 \pm 0.01 \mathrm{c}$ & $35.4 \pm 0.40 c$ \\
\hline & & $\begin{array}{c}\text { G7: AE-SN } \\
\text { mixture } \\
250 \mathrm{mg} / \mathrm{kgb} . w \mathrm{t}\end{array}$ & $2.50 \pm 0.05 \mathrm{c}$ & $3.15 \pm 0.32 b$ & $65.54 \pm 0.02 d$ & $42.4 \pm 0.12 b$ \\
\hline & & $\begin{array}{l}\text { G8: AE-SN } \\
\text { mixture } \\
500 \mathrm{mg} / \mathrm{kgb} . w \mathrm{t}\end{array}$ & $2.20 \pm 0.08 \mathrm{c}$ & $4.25 \pm 0.31 \mathrm{a}$ & $54.65 \pm 0.03 d$ & $46.0 \pm 0.33 a$ \\
\hline
\end{tabular}

Mean \pm SD values in each raw with different superscripts $(a, b, c, d)$ are significantly differentas compared to the control groups at $P<0.05 n=6$ rats/group.

Data in table (9) showed that, administration of gentamicin( GM) intra-peritoneal at dose of $100 \mathrm{mg} / \mathrm{kg}$ b.wt for 7 days caused a significant increased in level of MDA by (104.02\%)of the control negative value .The same treatment reduced the kidney content of intracellular GSH level by ( $51.13 \%$ ) of the control value. Higher values of MDA indicate the oxidative stress in GM treated group. The increase in MDA levels were attenuated by pre treatment with (AE-SN) leave or seeds and their mixture at 250 or $500 \mathrm{mg} / \mathrm{kg}$ b.wt for 21 days followed by concomitant administration of GM at $(100 \mathrm{mg} / \mathrm{kg} \mathrm{b.wt} \mathrm{ip)} \mathrm{for} 7$ days as follow, group 8 followed by group-7, group-5, group-6,group 3and group-4 respectively when compared with 
control (-ve). However, group-5 that treated with (AE-SN) of leave at $500 \mathrm{mg} / \mathrm{kg}$ b.wt had the similar values as compared to group- 6 that treated with (AE-SN) of seeds at $500 \mathrm{mg} / \mathrm{kg}$ b.wt. The completely attenuated for MDA levels were to group 8 that administrated with the highest level of leave and seed mixture at $500 \mathrm{mg} / \mathrm{kgb}$.wt when compared to control (-ve) group. Similary pre treatment with (AE-SN) seeds or leaves and their mixture at 250 and $500 \mathrm{mg} / \mathrm{kg}$ b.wt for 21 days followed by concomitant administration of GM at (100mg/kg b.wt ip) for 7 days markedly reduced suppuration in renal intracellular GSH level that was observed in GM group alone.The combined treatment of leave and seed extract was more effective than either agent alone in protecting against the suppuration in renal intracellular GSH induced by GM alone

Table (9): Effect of AE-SN leaves or seeds and their mixture on malondialdehyde (MDA) and reduced glutathione (GSH) levels in kidney tissue of nephrotoxic rats.

\begin{tabular}{|c|c|c|c|c|}
\hline \multicolumn{3}{|c|}{ Groups } & $\begin{array}{c}\text { MDA } \\
(\mu \mathrm{mol} / \mathrm{gm} \text { protein })\end{array}$ & $\begin{array}{c}\text { GSH } \\
(\mu \mathrm{mol} / \mathrm{gm} \text { protein })\end{array}$ \\
\hline \multicolumn{3}{|r|}{ G 1: Control - ve } & $42.22 \pm 0.2 \mathrm{~d}$ & $11.50 \pm 0.61 \mathrm{a}$ \\
\hline \multirow{7}{*}{ 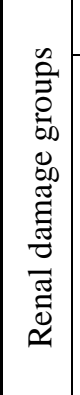 } & \multicolumn{2}{|r|}{ G 2: Control + ve } & $86.14 \pm 0.5 \mathrm{a}$ & $5.62 \pm 0.25 \mathrm{e}$ \\
\hline & \multirow{6}{*}{ 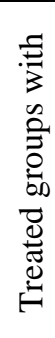 } & G3: AE-SN leave extract $250 \mathrm{mg} / \mathrm{kgb} . \mathrm{wt}$ & $72.32 \pm 0.7 b$ & $7.89 \pm 0.51 \mathrm{~d}$ \\
\hline & & G4: AE-SN seed extract 250mg/kgb.wt & $76.54 . \pm 0.6 \mathrm{~b}$ & $7.52 \pm 0.42 \mathrm{~d}$ \\
\hline & & G5: AE-SN leave extract $500 \mathrm{mg} / \mathrm{kgb} . \mathrm{wt}$ & $67.82 \pm 0.3 \mathrm{c}$ & $8.93 \pm 0.49 \mathrm{c}$ \\
\hline & & G6: AE-SN seed extract 500mg/kgb.wt & $67.91 \pm 0.4 \mathrm{c}$ & $8.52 \pm 0.65 \mathrm{c}$ \\
\hline & & G7: AE-SN mixture $250 \mathrm{mg} / \mathrm{kgb}$.wt & $57.32 \pm 0.4 \mathrm{~cd}$ & $9.99 \pm 0.53 b$ \\
\hline & & G8: AE-SN mixture 500mg/kgb.wt & $46.21 \pm 0.5 \mathrm{~d}$ & $10.72 \pm 0.62 \mathrm{a}$ \\
\hline
\end{tabular}

Mean \pm SD values in each raw with different superscripts $(a, b, c$,$) are significantly$ different as compared to the control groups at $\mathrm{P}<0.05 \mathrm{n}=6$ rats/group.

Data illustrated in table (10) showed that rats injected with a gentamicin (GM) intra-peritoneal at dose $100 \mathrm{mg} / \mathrm{kg}$ b.wt for 7 days only (+ve) had significantly reduced antioxidant activities of glutathione peroxidase (GPx), superoxide dismutase (SOD) and catalase (CAT) enzymes compared to control (-ve) group. The level of antioxidant enzyme 
was significantly improved by administration of (AE-SN) seeds or leaves and their mixture at 250 and $500 \mathrm{mg} / \mathrm{kg}$ b.wt for 21 days followed by concomitant administration of GM at $(100 \mathrm{mg} / \mathrm{kg}$ b.wt ip) for 7 days reversed the lower value of GPx, SOD and CAT induced by GM treatment. However leave plus seed extract pretreatment regimen was more effective than either agent alone. While the highest dose of leave and seed mixture has the ability to restore the antioxidant enzyme activity in GM treated groups in addition to nephroprotective effect.

Table (10):Effect of AE-SNleaves or seeds and their mixture on activities of antioxidant enzymes in kidney tissues ofnephrotoxic rats.

\begin{tabular}{|c|c|c|c|c|c|}
\hline \multicolumn{3}{|c|}{ Groups } & $\begin{array}{c}\mathrm{GPx}(\mathrm{nmol} / \mathrm{min} / \\
\text { mg protein })\end{array}$ & $\begin{array}{c}\text { SOD } \\
(\mathrm{U} / \mathrm{mg} \text { protein })\end{array}$ & $\begin{array}{c}\mathrm{CAT} \\
(\mathrm{nmol} / \mathrm{min} / \mathrm{mg} \\
\text { protein) }\end{array}$ \\
\hline \multicolumn{3}{|r|}{ G 1: Control - ve } & $66.15 \pm 3.11 \mathrm{a}$ & $82.31 \pm 0.02 a$ & $3.91 \pm 0.03 \mathrm{a}$ \\
\hline \multirow{7}{*}{ 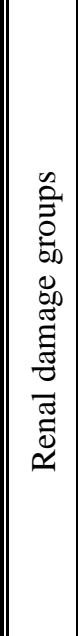 } & \multirow{7}{*}{ 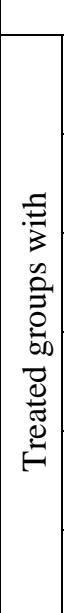 } & G 2: Control + ve & $42.32 \pm 3.15 \mathrm{~d}$ & $35.13 \pm 0.01 \mathrm{e}$ & $1.45 \pm 0.03 \mathrm{c}$ \\
\hline & & $\begin{array}{c}\text { G3: AE-SN leave extract } \\
250 \mathrm{mg} / \mathrm{kgb} . \mathrm{wt}\end{array}$ & $52.13 \pm 3.23 c$ & $50.32 \pm 0.02 d$ & $2.51 \pm 0.22 b$ \\
\hline & & $\begin{array}{c}\text { G4: AE-SN seed extract } \\
250 \mathrm{mg} / \mathrm{kgb} . \mathrm{wt}\end{array}$ & $50.16 \pm 3.35 c$ & $48.05 \pm 0.04 d$ & $2.00 \pm 0.13 b$ \\
\hline & & $\begin{array}{c}\text { G5: AE-SN leave extract } \\
500 \mathrm{mg} / \mathrm{kgb} . \mathrm{wt}\end{array}$ & $60.83 \pm 4.73 b$ & $65.14 \pm 0.01 c$ & $2.99 \pm 0.02 \mathrm{a}$ \\
\hline & & $\begin{array}{c}\text { G6: AE-SN seed extract } \\
500 \mathrm{mg} / \mathrm{kgb} . \mathrm{wt}\end{array}$ & $56.23 \pm 4.73 b$ & $64.52 \pm 0.03 c$ & $2.71 \pm 0.03 b$ \\
\hline & & $\begin{array}{c}\text { G7: AE-SN mixture } \\
\text { 250mg/kgb.wt }\end{array}$ & $55.23 \pm 4.73 b$ & $78.09 \pm 0.05 b$ & $3.01 \pm 0.01 \mathrm{a}$ \\
\hline & & $\begin{array}{l}\text { G8: AE-SN mixture } \\
\text { 500mg/kgb.wt }\end{array}$ & $62.34 \pm 4.52 \mathrm{a}$ & $80.67 \pm 0.02 a$ & $3.51 \pm 0.11 \mathrm{a}$ \\
\hline
\end{tabular}

Mean \pm SD values in each raw with different superscripts $(a, b, c$,$) are significantly$ differentas compared to the control groups at $P<0.05 n=6$ rats/group.

\section{Histopathological Results of Kidney:}

Microscopically, kidney of control negative rat revealed the normal histopathological structure of renal parenchyma (pict.1). Meanwhile, kidney of rat from control positive rat group showed congestion in the renal golmerular and blood vessels with vaculation of the endothelial cells 
.Extensive cell necrosis was observed in epithelial cells of the proximal tubules, some tubules contain castes, slight trophy was observed in some renal tubules and related glomeruli, and the interstitial tissues between the renal tubules showed inflammatory cells infiltration (pict. 2).Kidney of rat pre- treated with different doses of (AE-SN) leave or seed and their mixture showed recovering of normal glomerulus and renal tubules, as follow pretreatment of rats with (AE-SN) leave at high dose $500 \mathrm{mg} / \mathrm{kg} \mathrm{b}$.wt for 21 days followed by administration of GM markedly improved injuries in renal tissues. There were mild tubular epithelial degeneration, necrosis (grade1) epithelial cells of the proximal tubules, slight tubular cast, and slight inflammatory cell infiltrate in the interstial no vascular congestion, and no vacuolation of endothelium (pic3). pretreatment of rats with (AE-SN) seed at high dose $500 \mathrm{mg} / \mathrm{kg}$ b.wt followed by administration of GM decreased renal injuries. There were moderate degeneration necrosis grade II in tubular epithelium of the proximal tubules, slight tubular cast , mild congestion , and slight inflammatory cell infiltrate in the interstial (pic4). Similary, co administration of $500 \mathrm{mg} / \mathrm{kg}$ b.wt of leave and seed extract followed by administration of GM markedly improved injuries in renal tissues There were mild tubular epithelial degeneration, no necrosis was observed in epithelial cells of the proximal tubules, no tubular cast, and slight interstium cell infiltration, no vascular congestion, and no vacuolation of endothelium (pic5).

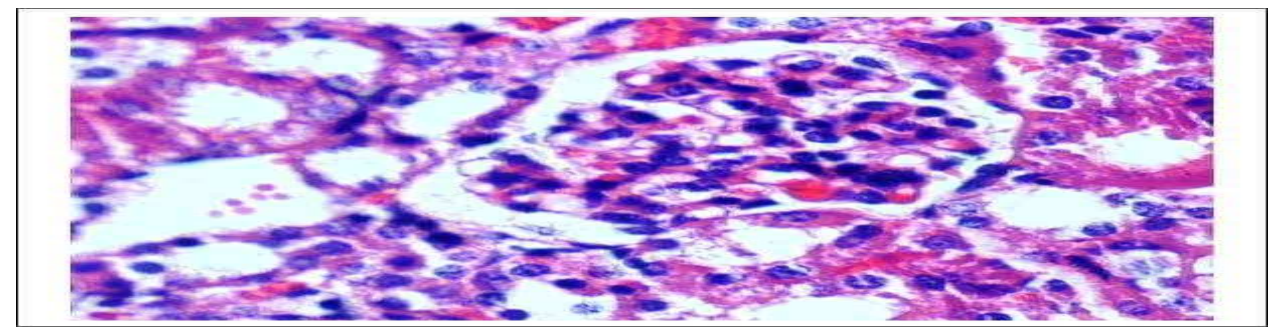

(pic.1) Sections in the kidney cortex of a control rat showing a glomerulus and renal tubules 


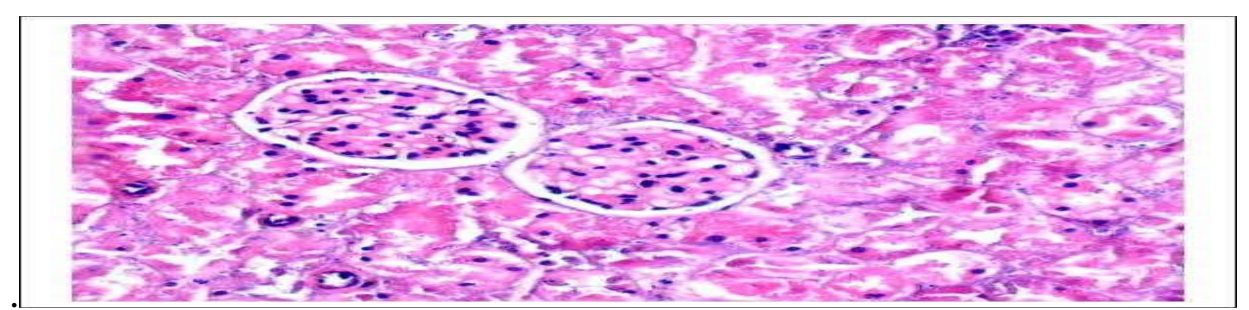

(pic 2) Section from renal tissues received gentamicin the section revealed grade III-IV tubular necrosis and tubular cast . the interstitial tissue moderate inflammatory cell infiltrate

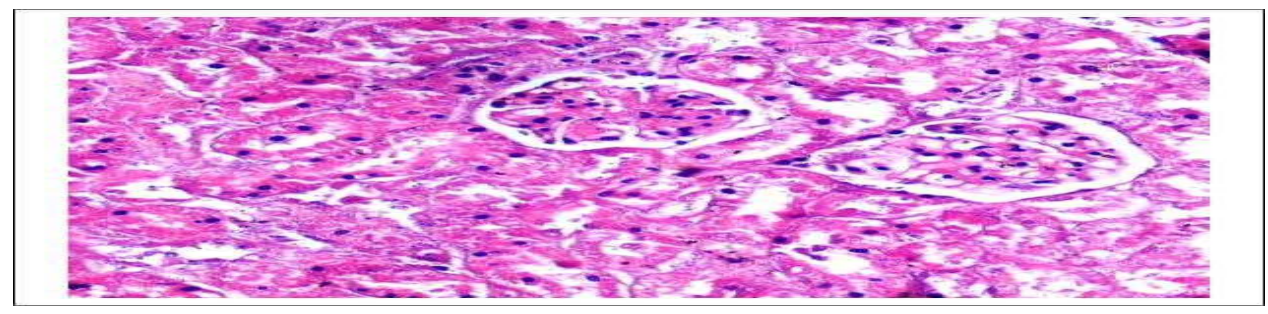

(pic 3) Section from renal tissues of rats pretreated with (AE-SN ) of leave at high does $500 \mathrm{mg} /$ and administration of GM. The section revealed grade Itubular necrosis and tubular cast .Most of the tubules show regenerative changes.

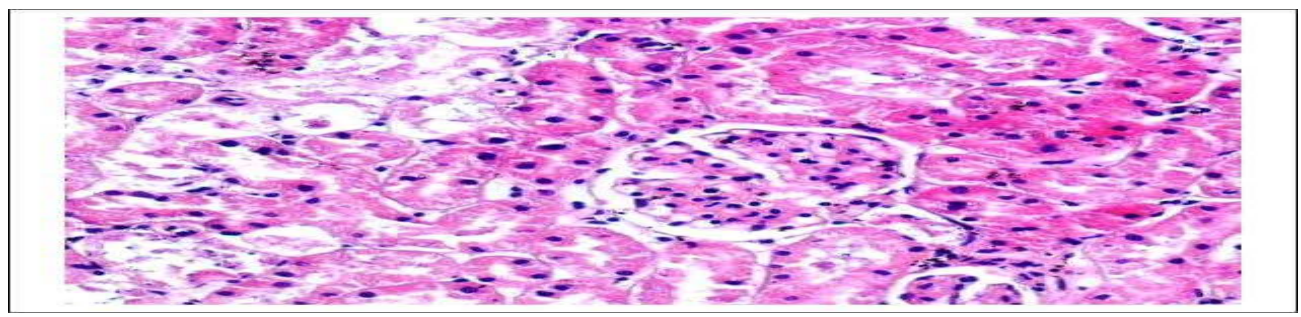

(pic 4) Section from renal tissues of rats pretreated with (AE-SN) of seed at high does $500 \mathrm{mg}$ and administration of GM. The section revealed grade II tubular necrosis and tubular cast .Many tubules show regenerative changes. 


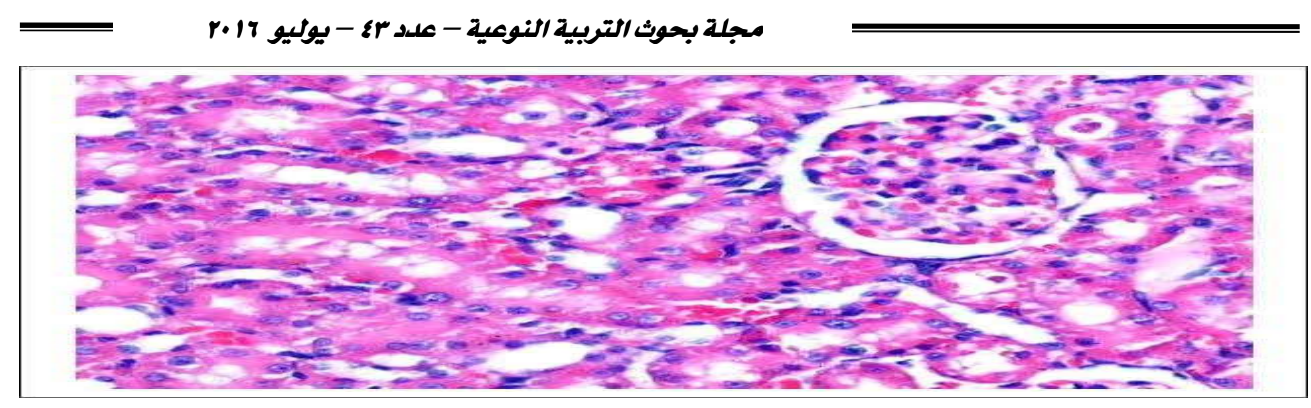

(pic 5) Section from renal tissues of rats pretreated with (AE-SN) mixture of leave and seed at high does $500 \mathrm{mg}$ and administration of GM. The section revealed mild tubularepithelial degeneration and no necrosis was observed in epithelial cells of the proximal tubules and no tubular cast

\section{Discussion}

Gentamicin (GM) is an antibiotic widely used in treating severe gram-negative infections. However, its clinical use is limited by its nephrotoxicity. Several lines of evidence indicate that free radicals are important mediators of gentamicin nephrotoxicity. Therefore, the aim of this study was to investigate the possible protective effect of aqueous extract of AE- SN leaves or seeds and their mixture with different doses, on gentamicin-induced nephrotoxicity . In addition, another possible mechanism regarding the action of gentamicin is that gentamicin may increase the production of hydrogenperoxide (H2O2), and it is well known that oxygen and $\mathrm{H} 2 \mathrm{O} 2$ causes the contraction of mesangial cells, modify the filtration surface area and ultimately reduce the GFR.(Lopez-Novoa etal.,2011) and (Hozayen etal.,2011) .

Therefor, there is a continuous search for agents which provide neoprene-protection against the renal impairment caused by drugs like gentamicin(Ali, 2006). Antioxidants from plant are of increasing interest to consumers because of their roles in the maintenance of human health. Various phenolic compounds such as flavonoids, phenolic acids, saponins and tannins possess diverse biological activities and are thought to be beneficial for reducing tissue damage induced by oxidative stress.(Cai etal., 2003),(Acharya and Shrivastava,2008),(Kumar etal.,2012) and(Mohana et al ., 2012) 
Body weight is frequently the most sensitive indicator of adverse effects of xenobiotic. So, it is considered as a determinant parameter of toxicity testing. Increased catabolism, seen in acute renal failure, results in acidosis which is accompanied by anorexia. Hence, oral feed intake decreases and this causes body weight loss (Khundmiri etal ., 2004)

Throughout our study, it was apparent that GM administration produced toxicity in rats as examined by a gradual decrease in feed intake, a very highly significant decrease in body weight gain and increased kidney weight observed. Excessive GM ingestion disturbs the metabolism of most nutrients in the diet resulting in malnutrition this may be one of the reasons for decreased body weight in GM- administered rats. These results were in agreement with Bello and Chika, (2009) and Lakshmi and Sudhakar (2010)who illustrated that GM induced renal disorders which could be due to the alteration in their eating behavior, as results of the cytotoxic effect of GM or to renal tubular injury affecting re-absorption of water leading to dehydration (and /or inflammation Kidney damage was also marked by elevated relative kidney weight due to the increase in glomerulus volume and other cellular changes.

Pre- treatment with aqueous extracts of Solanum Nigrum Linn(AE$\mathrm{SN})$ seeds or leaves and their mixture showed marked ameliorations on food intake and body weight gain for gentamicin intoxicated rats as compared to gentamicin control group. The kidney weight showed significant decrease in rats pre -treated with (AE-SN) leaves or seeds and their mixture concomitant with GM as compared with those of gentamicin control group. These effects could be associated with the alterations in nutrient absorption and metabolic utilization after treatments. This protective effect may be due to the presence of nutrients and Polyphenols present in Solanum nigrum leave and fruits as shown in chemical analyses of our result which showed that .Ash, fiber, total protein and moisture contents were higher in the leaves compared to the seeds. These results in the same line with Akindahunsi and Salawu (2005) who concluded that solanum nigrum has high nutritional value and is recommended as a cheap source of plant protein, energy and mineral elements such as magnesium and phosphorus. 
Also our result indicated that solanum nigrum L. leave and seed had many elements very important for increasing appetite and feed intake like mineral and vitamins. These elements were founds in the solanum nigrum $\mathrm{L}$. leave more than in seeds as sodium, potassium, calcium ,phosphor ,Magnesium , and iron . These results in agreement with Dhellot etal., (2006) who reported that $S$. nigrum contains high levels of magnesium and phosphorus but relatively low level of zinc. Solanum nigrum is a medical plant rich in the phytochemicals and vitamin $\mathrm{C}$ and $\mathrm{E}$ which act as natural antioxidant compound as Polyphenols and flavonoids. These result in agreement with Akubugwo etal.,(2007) and Hsiu etal., (2010) who recorded that oxalate levels were high in both leaves and seed of S. nigrum, and that sterols and tannins were below detectable levels in the seed. Apart from total phenols and flavonoids, the level of other studied phytochemicals were higher in the leaves relative to the seed. Pre treated with aqueous extracts of Solanum Nigrum Linn(AE- SN) leaves in a dose of 250 or $500 \mathrm{mg} / \mathrm{kg}$ bwt were more effective in reversible fee $\mathrm{d}$ intake and body weight than those administrated with seed extract in a dose of 250 or 500 $\mathrm{mg} / \mathrm{kg} \mathrm{b}$.wt. this may be due to the differences in chemical composition of them .While the mixture of them at $500 \mathrm{mg} / \mathrm{kg} \mathrm{b}$.wt normalized feed intake and restored body weight and kidney weight near to the normal.

Kidney is an important organ actively involved in maintaining homeostasis of the body by reabsorbing important material and excreting waste products so, kidney functional markers such as urea, uric acid and creatinine are the main indicators of renal dysfunction(Karahan, et al., 2005) and (Arthur et al., 2006).Urea is the nitrogen containing end product of protein catabolism. The concentration of urea is elevated when glomerulus filtration rate (GFR) is markedly decreased in renal pathies. Moreover, urea concentration begins to rise only after parenchymal tissue damage. (Safa etal., 2010). Thus, serum urea concentration is sometimes considered a more reliable renal function predictor than serum creatinine(Sharma, 2011). While creatinine derives from endogenous sources by tissue creatinine breakdown and its clearance enables a quite good estimation of the GFR. Plasma creatinine concentration is an important 
index than the urea concentration in the first phases of kidney disease(AlWabel et al., 2005).

Gentamicin activates the platelet activation factor causing local vasoconstriction and thus restricts the renal blood flow and ultimately GFR(Polat et al., 2006). Many studies supported that oxidative stress is the major contributor in GM-induced nephrotoxicityand the increase in serum urea and creatinine in rats could be attributed to the free radical that inducedoxidative damage and serum concentration ofcreatinine and urea depends largely on the glomerular infiltration. The change in these two parameters together with the histologicalresults indicate a reduction in the glomerular filtration rate as aresult of gentamicin intoxication ( Nitha and Janard, 2008) and (Saleemi et al., 2009). The results of gentamicin-induced nephrotoxicity in our study are in the same line with those documented previously. In our results GM administrated at $100 \mathrm{mg} / \mathrm{kg}$ b.wt ip to rats showed significant increase in the levels of blood ureanitrogen, uric acid and creatininecompared to normal control group. These increasesare mainly caused by increased production of ROS which is the mediators of tissue damage and finally leads to altered kidney function and renal failure.

Pretreatment with (AE-SN) leaves or seeds alone andtheir mixtureforall intoxicated groups displayed nephroprotective action by lowering the blood urea nitrogen, uric acid and creatinine level when compared to intoxicated rats $(+)$.Pretreatment withLeave or seeds extract of the plant alone exhibited varying degree of therapeutic effects in renal damage whereas combination of both displayed synergistic effect. We observed that renal markers were brought back to normal on treatment with the extract of Solanum Nigrummixture at high dose. These result in the same line with Arulmozhi et al., (2010) who explained that,S. nigrum leaves and seeds are a source of bioactive compounds (saponins, glycosides, tannins, alkaloids ascorbic acid, phenolic and terpenoids) with potential health promoting actions. Flavonoids are oxidized by radicals resulting in a more stable and less reactive radical. The Phytoconstituents detected in the plant materials may be responsible for their nephroprotective activity (Yarnell and Abascal 2007). Flavonoids can also inhibit the activity of many 
enzymes such as Xanthines oxidase, peroxidase and nitric oxide syntheses, which are supposed to involve in free radical generation (Al-Qirim etal., 2008).(Abd-Elkawy et al., 2013).

Albumin is the main contributor to the plasma osmotic pressure and is synthesized in the liver. It helps in the transport of drugs, hormones and enzymes. Albumin level decreases in kidney disorders, malnutrition, increased fluid loss during extensive burns, and decreased absorption in gastrointestinal diseases. (Abdel-Raheem etal., 2010). Hyperalbuminemia may result from impaired synthesis, loss through urine or feces, (Jain and Singhai 2010). in the present study, the results of albumin, globulin and total protein revealed that mean serum concentration of albumin $(\mathrm{g} / \mathrm{dl})$, globulin $(\mathrm{g} / \mathrm{dl})$ and total protein $(\mathrm{g} / \mathrm{dl})$ decreased significantly $(\mathrm{P} \leq 0.01)$ in GM - intoxicated group as compared to normal control group, which could be associated with necrosis of proximal tubules. These results were in accordance with safa etal., (2010) who revealed that administration of gentamicin induced a renal failure characterized with reduced glomerular function which it reflected by marked significant decrease in serum total protein, albumin and globulin concentration and increased proteinuria(Kumare al., 2004 )chronic nephropathies leads to increased glomerular permeability and excessive protein filtration.

Pre- treatment with (AE-SN) extract significantly improved values of albumin, globulin and protein in treated groups exhibited its nephroprotective effects when compared to control positive groupthis could be due to the ability of (AE-SN) extract to partially ameliorate the tubular necrosis. These results are in agreement with the results of Kumar et al., (2001) and Harika etal., (2013) who showed that significant nephroprotective and antiurolithiatic activity ofSolanum Nigrummay be owed to the presence of important constituents like glycoprotein, polyphenolic compounds and flavonoids.

The kidneys are the key organs to maintain the balance of the different electrolytes in the body and the acid-base balance. Progressive loss of kidney function results in a number of adaptive and compensatory renal 
and extrarenal changes that allow homeostasis to be maintained with glomerular filtration rates in the range of $10-25 \mathrm{ml} / \mathrm{min}$. With glomerular filtration rates below $10 \mathrm{ml} / \mathrm{min}$, there are almost always abnormalites in the body's internal environment with clinical repercussions as, retention of nitrogenous waste products of metabolism in the blood. In addition to this, there is a failure of regulation of fluid and electrolyte balance along with endocrine dysfunction Ateşşahin etal., (2003) and Ali, (2006) who reported that, injection with GM at dose rate of $100 \mathrm{mg} / \mathrm{kg}$ intra-peritoneal caused nephrotoxicity in rats. GM is actively transported into proximal tubules, here it accumulates and damages the tubular cells, hence; alters the renal circulation leading to reduced glomerular filtration rate(GFAR), which resulted in decreased kidney ability to, extract body waste, maintain body fluid and electrolyte balance and decreased synthesis of essential hormone( El-Tantawy etal., 2013) .

In our results GM administrated at $100 \mathrm{mg} / \mathrm{kg}$ b.wt ip for 7 days to rats showed significant increase in serum sodium, potassium and phosphor while caused a significant decrease in serum calcium .Compared to normal control group. These results in agreement with Alcázar-Arroyo, (2008) Who showed that total body content of sodium is the main determinant of extracellular volume and therefore disturbances in sodium balance will lead to clinical situations of volume depletion or overload: Volume overload due to sodium retention can occur with glomerular filtration rates below 25 $\mathrm{ml} / \mathrm{min}$ and leads to edema, arterial hypertension and heart failure. On the other hand, the ability of the kidneys to excrete potassium decreases proportionally to the loss of glomerular filtration. Stimulation of aldosterone and the increase in intestinal excretion of potassium are the main adaptive mechanisms to maintain potassium homeostasis until glomerular filtration rates of $10 \mathrm{ml} / \mathrm{min}$ (Balakumar et al., 2008). While moderate metabolic acidosisis common with glomerular filtration rates below $20 \mathrm{ml} / \mathrm{min}$, and favors bone demineralization due to the release of calcium and phosphate from the bone, chronic hyperventilation, and muscular weakness and atrophy. Hypocalcaemia should always be corrected before metabolic acidosis in chronic kidney disease Humes et al. ,(2008).In addition to 
(Nirajet al., 2011) reported that, muscle spasms are a painful problem for the person with chronic kidney failure. It appears to be at least partially due to low calcium levels due to the lack of 1-25 dihydroxycholecalciferol. This leads to decrease intestinal absorption of calcium and decreased renal absorption of calcium as well as decreased absorption of calcium from the bone too.

Pretreatment with (AE-SN) leaves or seeds alone and their mixture at 250 or $500 \mathrm{mg} / \mathrm{kg}$ b.wt for 21 days concomitant with GM at dose rate of $100 \mathrm{mg} / \mathrm{kg}$ b.wt for additional 7 days displayed nephroprotective action by reducing serum sodium, potassium and phosphorus and increased calcium level in the serum .these result in agreement with Perez, et al., (1998) who concluded that,Solanumnigrum fruit improved kidney function by lowering serum sodium level and potassium level .

In the present study, nephrotoxicity of renal by administration of gentamicin at $100 \mathrm{mg} / \mathrm{kgb}$.wt ip for 7 days resulted in a significantincrease in the renal renin hormone and parathyroid hormone which showed significant decreases in erythropoietin (EPO) and vitamin D. The function of these hormones are to improve clearly near to the normal level with the co administration with mixture of(AE- $\mathrm{SN})$ leave and seed.These results are in agreement with Remuzz et al., (2005) and Kotoko and Kuska, (2008) , who reported that in chronic patients with very advanced reduction of glomerular filtration the residual juxtaglomerular cells seem to function at maximal level and the values of plasma renin activity were found to be higher and no further increase of renin secretion can be expected.

Gentamicin generates excess production of free radicals that could play a significant role in the progression of renal injuries including array of bimolecular such as membrane lipids, protein and nucleic acids particularly in some organelles like mitochondria and lysosomes of renal tissues(Shankar etal .,2011). Increased propagation of ROS confers the peroxidationof attached polyunsaturated fatty acidsto biomembranes (Hamid etal., 2013a).Gentamicin-induced lipid peroxidation impaired the cellular function and provokes necrosis. This evolution of ROS may 
stimulate the activation or expression of pro inflammatory mediators which could contribute to progressive kidney damage induced by GM (Hamid etal.,2103b).

In the present study, administration of gentamicin at $100 \mathrm{mg} / \mathrm{kgb}$.wt ip for 7days resulted in a significantincrease in the renal tissue content of MDA indicating increased lipid peroxidation which implicates the renal oxidative stress. Moreover,Gentamicin caused a significant decrease in the activities of SOD, GPx and CAT. Antioxidant enzymes and non enzymatic GSH. These decreases could be due toinefficient scavenging of ROS which might be implicated too xidative inactivation of enzymes. These results are in agreement with Romero etal ., (2012)and Stojiljkovic et al., (2012) .The reduced level of GSH might be due to reactive oxygen intermediates generated during gentamicin metabolism, which led to glutathione oxidation and lipid peroxidation. The reduced form of GSH, therefore, became readily oxidized to GSSG on interacting with the free radicals.(Banday etal., 2008). Catalase acts as a preventive antioxidant and plays an important role in protection against the deleterious effects of reactive oxygen species (ROS).The significant decrease in the activityof catalase during gentamicin ingestion indicates inefficient scavenging of $\mathrm{H} 2 \mathrm{O} 2$ (Al-Majed etal., 2007).GPx has a role in defending cells against oxidative stress and this in turn involves GSH as a cofactor. GPx catalyses the oxidation of GSH to GSSGat the expense of H2O2 .Decreased GPx activity was observed in the GM -treated group. This decreased activity may be implicated to either free radical dependent inactivation ofenzyme or depletion of its co-substrate (i.e.GSH) (El-Tantawyet al., 2013).

Solanum nigrum Lin is reported to act as an effective antioxidant against diseases and degenerative processes caused by oxidative stress. (Raju etal., 2003), (Rani and Khullar.2004) and (Lee and Lim ,2006) , and (Adebooye et al., 2008) who concluded that the antioxidant property of the extract may be due to the presence of a high content of polyphenolic compounds such as Gallic acid, catechins, Caffeic acid, epicatechin, rutinand, narigenin ,Furthermore, the antioxidant property of the extract may therefore be due to the presence of high content of steroids, vitamin $\mathrm{C}$, 
vitamin E and $\beta$ - carotene. In addition, saponins(Jainu and Shyamala Devi. 2004),(An etal., 2006),(Hsieh et al., 2008) and (Loganayaki etal., 2010 ) Solanum nigrum glycoprotein has a strong scavenging activity against lipid peroxidation peroxyl radicals (Lin et al 2008).(Hsiu -Chen, 2010) reported that, leaves were found to be richer in Polyphenols than stem and fruit.

Co-administration of (AE-SN) leave and seeds mixture concomitant with GM significantly altered the activities of both the enzymatic and nonenzymatic antioxidants to near normal levels, which proves to be a potent antioxidant our finding correlated with recent reports of .The mixtureof (AE-SN ) leaves and seeds more effective than each one alone, as the mixture having strong antioxidant and cellular anti inflammatory properties improved the oxidant status., also its ability of antiinflammatory activity and antioxidant status. Therefore, they could inhibit lipid peroxidation by scavenging ROS.High content of Polyphenols, alkaloids and saponins in Solanum nigrum extract (SNE) contributes free radical scavenging and antioxidant activities(Natarajan etal., 2006) and (Abd Elkawy et al ., 2013). The nephroprotective effect of $S$. nigrum in the present study, against gentamicin induced nephrotoxicity is in harmony and supports the previous reports indicating the antioxidant effect.

Histopathological finding in this study agrees with earlier reports which improved that gentamicin induces conspicuous and characteristic changes inlysosomes of proximal tubular cells consistent with the accumulation of polar lipids (myeloid bodies). These changes are preceded and accompanied by signs of tubular dysfunctions or alterations (release of brushborder and lysosomal enzymes; decreased reabsorption of filtered proteins) (Hozayen etal., 2011) and (Gowda and Swamy 2012).

In current study, control positive group exhibited severe necrotic changes in the proximal convulated tubule. These include: pyknotic nuclei, hyperchromaticand massive dilation of the capillaries, massive tubular epithelial cell necrosis, karryorehexsis and karryolyticchanges in the nucleus, sever congestion with massive glomerulli tuft lobulation and necrosis. Increase inintracellular free oxygen radicals can initiate 
irreversible cellular injury process leading to tubular necrosis and tubular degeneration in renal tissues (Martínez-Salgado etal., 2007) and (Hamid etal.,2013). Scavenging of free oxygen radicals prevent irreversible renal cell injury andnecrosis( Walker etal., 1999) .Many studies proposed that mediation of reactive oxygenmay have linked with degenerative tubular effects of gentamicinIn a study, reactive oxygen species have been identified as inducers of proximal tubular necrosis and acute renal failure in gentamicin-induced nephrotoxicity.

In current study tubular necrosis, as a sign of irreversible injury in most sections examined from group 2.( $\mathrm{AE}-\mathrm{SN})$ leave and seed mixture as an antioxidant inhibits lipid peroxidation and prevents renal cell injury. The results of the present study showed that mixture treatment affected biochemical values in line to pathological findings.

\section{CONCLUSION}

The results of the present study showed that the aqueous extract of $S$. nigrum leave or seedand their mixture can offer protection against the deleterious renal side effects of gentamicin. According to the biochemical findings, which were supported by histopathological evidences.

\section{References}

- Abd-Elkawy ,M ., Soliman,G. and Abd-El Rehim ,E. (2013): Effect of Solanumnigrum Linn against Lambda Cyhalothrin-Induced Toxicity in Rats.J of Phar and BioloScie, V 5, Issue 5: 55-62.

- Abdel-Raheem, I.T., El-Sherbiny,G.A. and Taye, A.(2010): Green tea ameliorates renal oxidative damage induced bygentamicin in rats, Pakistan Journal of Pharmaceutical Scie, 23, 21-28.

- Acharya, D. and Shrivastava, A. (2008): Indigenous Herbal Medicines: Tribal Formulation and Traditional Herbal Practices, Aavishkar Publishers Distributor, Jaipur- Ind.

- Adebooye, O .C., Vijayalakshmi, R. and Singh, V. (2008) :Peroxidase activity, chlorophylls and antioxidant profile of two leaf vegetables $\begin{array}{llll}\text { (SolanumnigrumL.andAmaranthuscruentus } & \text { L.) under six pretreatment }\end{array}$ 
methodsbefore cooking. International Journal of Food Science and Technology.;42:173-178.

- Afzal, M., Afzal, A., Jones, A. and Armstrong, D. (2002): A rapid method for the quantification of GSH and GSSG in biological samples.Cited in: Oxidative stress biomarkers and antioxidant protocol.Edr. Armstrong D., Humana Press, 117-122.

- Akindahunsi, A.A. and Salawu, S.O. (2005):Phytochemical screening and nutrient-anti nutrient composition ofselected tropical green leafy vegetables. Afr. J.Biotech., 4: 497-501.

- Akubugwo, I.E. , Obasi ,A.N.andGinika, S.C. (2007) :Nutritional Potential of the Leaves and Seeds of Black Nightshade-SolanumnigrumL. Varvirginicumfrom Afikpo-Nigeria. Pakistan J of Nutr 6 (4): 323-326.

- Ali, B.H., Al-Wabel, N., Mahmoud, O., Mousa, H.M. and Hashad, M.(2005):Curcumin has a palliative action on gentamicin-induced nephrotoxicity in rats. Fundamental Clinical Pharmacology, 19, 473 -477.

- Ali, B.H. (2006): Gentamicin nephrotoxicity in humans and animals: some recent General Pharmacology, 26, 1477-1487.

- Al-Majed, A.A., Mostafa, A.M., Al-Rikabi,A.C. and Al-Shabanah, O.A. (2007): Protective effects of oral arabic gum administration on gentamicin induced nephrotoxicity in rats, Pharmacological Research, 46, 445 -451.

- Al-Qirim,T., Syed, M.Z., Moyad, S., Ghassan, S. and Naheed, B. (2008): Effect of Solanumnigrum on immobilization stress induced antioxidant defense changes in rat. Res J Biol Sci. 3:1426-9.

- Al-Wabel, N., Mousa H.M. and Hashad M.(2005): Curcumin has a palliative action on gentamicin-induced nephrotoxicity in rats. Fundamental Clinical Pharmacology, 19, $473-477$.

- An, L., Tang, J.T.and Liu, X.M. (2006): Review about mechanisms of anticancer of Solanumnigrum [Article in Chinese] ZhongguoZhong Yao ZaZhi;31:1225-6.

- A.O.A.C.(2000): Official Methods of Analysis ,Association Of Official Agriculture chemists ,17 Ed., vol.11, Virginia,U.S.A.

- Armitage, P. G., Berry and J.M.S., Matthews, (2002): Statistical Methods in Medical Research. 4th Ed. Blackwell Science Ltd. 
- Nephroprotective Effect of Aqueous Extract of Solanum Nigrum Linn leaves or seeds

- Arthur, C., Guyton, S., Joh ,E. and Hall,E. (2006): Text book of medical physiology 11th ed: pp. 310. Philadelphia, Saunders Publisher.

- Arulmozhi,V. ,M., Karthishwaran,K., Dhamodharan,G. and Mirunalini,S. (2010): Antioxidant and antihyperlipidemic effect of Solanumnigrum fruit extract on the experimental model against chronic ethanol toxicity.Pharmacogn Mag. 6(21): 42-50.

- Arulmozhi,V., Krishnaveni,M. and Mirunalini, S. (2012): Protective effect of Solanumnigrum fruit extract on the functional status of liver and kidney against ethanol induced toxicityJBiochem Tech 3(4):339-343.

- Atanu,f.o.,Ebiloma,u. and Ajayi,E.I. (2011): A review of the pharmacological aspects of SolanumnigrumLinnBiotech and MolecBiolo Review 6(1), 001-007.

- Ateşşahin, A.,Karahan, I. , S. Yilmaz, A.O. Çeribaşı and I. Pirincci(2003): The effect of manganese chloride on gentamicin-induced nephrotoxicity in rats, Pharmacol Res 48 , pp. 637-642.

- Balakumar, P., Chakkarwar, V.A., Kumar ,V., Jain ,A., Reddy, J and Singh M. (2008): Experimental models for nephropathy. J Renin Angiotensin Aldosterone Syst 9(4):189-95.

- Banday, A.A., Farooq, N., Priyamvada, S., Yusufi, A and Khan, F.(2008): Time dependent effects of gentamicin on the enzymes of carbohydrate metabolism,brush border membrane and oxidative stress in rat kidney tissues, Life Sciences, 9-10(82), 450-459.

- Barbier, O., Jacquille G.t. , Tauc M. , Cougnan, M and Poujeol P. (2005) : Effect of heavy metals on, and handling by kidney, Nephron Physiol. 99 ,105110.

- Bartholomev,R.J. and Delany ,A.(1966):ProcAust .Assoc. Biochemists .1,214.

- Bello , S. O. and Chika ,A. (2009): Dose-Dependent Amelioration of Gentamicin-Induced Nephrotoxicity in Adult Swiss Albino Rats by Vitamin Bcomplex - A Preliminary Study.TropicalJ of Pharma Rese, 8 (2): 111-116.

- Cai,Y., Luo,Q., Sun ,M., and Corke,H.(2003): Antioxidant activity and phenolic compounds of 112 traditional Chinese medicinal plants associated with anticancer. Life Sci;74: 2157-84 
- Carleton, H. (1979) :Histological Techniques, 4th Edition, Oxford University New York, USA,Toronto gentamicin and cisplatin-induced nephrotoxi rats. Asian Pac J Trop Biomed 2012; S1754-S1763.

- Dhellot, J.R., E. Matouba, M.G. Maloumbi, J.M. Nzikou, M.G. Dzondo, M. Linder, M. Parmentier,M and Desobry, S. (2006):Extraction and nutritional properties of Solanumnigrum L. seedoil.Afr. J Biotech., 5: 987-991.

- El_Tantawy, W ., MohamedSH, and Abd Al Haleem, K. (2013):Evaluation of biochemical effects of Casuarinaequisetifolia extract on gentamicin induced nephrotoxicity and oxidative stress in rats. Phytochemical analysis. J. Clin. Biochem. Nutr. ; 53(3): 158-165.

- Farombi ,E and Ekor ,M (2006):Curcumin attenuates gentamicin - induced renal oxidative damage in rats .Medicine ,44(9):1443-1448.

- Fossati, P., Prencipe, L. and Berti, G. (1980):Use of 3, 5 dichloro-2-hydroxyl benzene sulfonic acid /4-amylphenazone chromogenic system in direct enzymatic assay of uric acid in serum and urine. Clin. Chem.; 26: 227-231

- Gogoi ,P. and Islam, M .(2012):Phytochemical Screening of SolanumnigrumL and S.myriacanthusDunal from Districts of Upper Assam, India.IOSR J of Phar 2( 3) 455-459.

- Gowda, K.P., and Swamy, B.M. (2012): Histopathological and nephroprotective study of aqueous stem bark extract of Ficusracemosain drug induced nephrotoxic rats. IOSR Journal of Pharmacy.; 2(2):265-270.

- Grases , F., Prieto,R., Fernandez-Cabot,R ., Costa-Bauzá,A ., Tur,F., and Torres,J.(2015): Effects of Polyphenols from Grape Seeds on Renal Lithiasis.Oxidative Medicine and Cellular Longevityhttp://dx.doi.org/10.

- Hamid, N., Nematbakhsh.,M. and Rafieian-Kopaei ., M .(2013):Ethanolic Extract of Garlic for Attenuation of Gentamicin induced Nephrotoxicity in Wistar Rats. Iranian Journal of Kidney Diseases.2013; 7(5):376-386.

- Hamid, N., Nematbakhsh,M., Shamin, G., Roya, A., Najmeh,S., and RafieianKopaei,M .(2013): Preventive and Curative Effects of Ginger Extract Against Histopathologic Changes of Gentamicin-Induced Tubular Toxicity in Rats. International Journal of Preventive Medicine.; 4(3), 316-321. 
- Nephroprotective Effect of Aqueous Extract of Solanum Nigrum Linn leaves or seeds

- Harika, H., Raju, D ., krishna,G., $\quad$ Yesu,B $\quad$ and Priyanka,A.(2013):Nephrotoxicity and Urolithiasis Activity of Solanumnigrum.IJRPS , 4(1), 35- 46.

- Hozayen,W., Bastawy,M. and Elshafeey,H.(2011):Effects of Aqueous Purslane (PortulacaOleracea) Extract and Fish Oil on Gentamicin Nephrotoxicity in Albino Rats.

- Hsieh C.C, Fang H.L and Lina W.C. (2008):Inhibitory effect of Solanumnigrum on thioacetamide induced liver fibrosis in mice. $\mathbf{J}$ Ethnopharmacol.;119:117-21.

- Hsiu -chen H., Kai - yang,s. and Jen-Kun ,L.(2010): Chemical Composition of Solanumnigrum Linn Extract and Induction of Autophagy by Leaf Water Extract and Its Major Flavonoids in AU565 Breast Cancer CellsJ. of .Agril and Food Chem.,58(15):8699-708.

- Humes, H.D.,Sastrasinh,M and Weinberg,M.J.(2008): Calcium is a competitive inhibitor of gentamicin-renal membrane binding interactions and dietary calcium supplementation protects against gentamicin nephrotoxicity.J Clin Invest.; 73(1): 134-147.

- Husdan, H. and Rapoport, A. (1968): Estimation of creatinine by Jaffe reaction method.Clin. Chem.; 14: 222-228.

- Jainu, M. and Shyamala Devi, C.S.(2004):Antioxidant effect of Methanolic extract of Solanumnigrum berries on aspirin induced gastric mucosal injury. Indian J Clin Biochem.;19:57-61.

- Jain,A .and Singhai, A.(2010):Effect of MomordicadioicaRoxb on gentamicin model of acute renal failure, Natural Product Research, 20, 1379-1389.

- Jia,Z.,Mengcheng,T. and Jianming,W.(1999): The determination of flavonid contents in mulberry and their scavenging effect on superoxide radicals.Food chem. 64:555-559.

- Karahan, I., Atessahin, A., Yilmaz S. , Ceribasi A. and Sakin F. (2005) : Protective effect of lycopene on gentamicin induced oxidative stress and nephrotoxicity in rats, Toxicology215 pp. 198-204.

- Khundmiri,S. Asghar, J.,.Banday,A.A., Khan,F., Salim.S., Levi, M., and Yusufi. A.N.K (2004) :Effect of ischemia and reperfusion on enzymes of carbohydrate metabolism in rat kidney . Nephrol.17, 377-383. 
مجلة بحوث التربية النوعية - علد rا - يوليو 17 .

- Kotoko,f., and Kuska.(2008):Plasma Renin activity in patients with acute and chronic renal insufficiency treated by haemodialsis .kidneyInt. 33(6):1107-12.

- Kumar, V.P., Shashidra, S., Kumar, M.M., and Sridhara, B.Y.(2001): Cytoprotective role of Solanumnigrum against gentamycin induced kidney cell (Vero cells) damage in vitro. Fitoterapia.;72:481-6.

- Kumar ,G., Banu,S.G., Vanitha .,P.P., Sundararajan, M. and Rajasekara, P.M. (2004): Hepatoprotective activity of TrianthemaportulacastrumL. against paracetamol and thioacetamide intoxication in albino rats, Journal of Ethnopharmacology, 92, 37-40.

- Kumar, S.V., Sanjeev, T. and Ajay, S.A.( 2012) : Review on hepatoprotectiveactivity of medicinal plant. IJARPB; 1: 31-38.

- Lakshmi, B .and Sudhakar, M.(2010): Protective effect of Zingiberofficinale on gentamicin-induced nephrotoxicity in rats. International Journal of Pharmacology . 2010;6(1):58-62.

- Lakashmi, M., Reedy ,u. and Rany ,T. (2012):A review On Medicinal plants For Nephroprotective activity Asian J of Pharm and Clin Rese;5(4).

- Lee ,S.J., and Lim (2006): 150-kDa glycoprotein isolated from SolanumnigrumLinn stimulates caspase-3-activation and reducesinducible nitric oxide Production in HCT-116 cells, Toxicology, 20(7), 1088-1097.

- Lin ,H.M., Tseng ,H.C., Wang, C.J., Lin, J.J., Lo, C.W., and Cho, F.P.(2008): Hepatoprotective effects of Solanumnigrum Linn extract against $\mathrm{CCl}_{4}$ induced oxidative damage in rats. ChemicoBiol Interact.;171:283-93.

- Loganayaki, N., Siddhuraju, P. and Manian S.(2010): Antioxidant activity of twotraditional Indian vegetables: Solanumnigrum L. and Solanumtorvum L. Food Sci. Biotechnol; 19:121-127.

- Lopez-Novoa, J.M., Quiros, Y., Vicente, L., Morales, A.I. and LopezHernandez FJ.(2011): New insights into the mechanism of aminoglycoside nephrotoxicity: an integrative point of view. Kidney Int .;79(1):33-45.

- Martínez-Salgado , M ., López- Hernández F.J. and López-Novoa J.M. (2007):Glomerular nephrotoxicity of aminoglycosides, Toxicol. Appl. Pharmacol. 223. 86-98.

- Mohana L,S., Reddy , u.k. and Rani ,K.S .(2012): Areview on medicinal plant for nephroprotective activity Asion J of pharm and clinic resh, 5(4). 
- Nephroprotective Effect of Aqueous Extract of Solanum Nigrum Linn leaves or seeds

- Mondi, S.,Harika,K ,Raghavendar,R., and Chidrawar,V., and Rao ,u.(2014): A comprehensive review of nephroprotective medicinal plants Treatment of plague with gentamicin or doxycycline in a randomized clinical trial in Tanzania, Clinical Infectious Diseases, 5(42), 614-621.

- Natarajan, S. K, Basivireddy, J., Ramachandran, A., Thomas, S., Ramamoorthy, P., Pulimood, A.B., Jacob, M. and Balasubramanian, K.A. (2006) : Renal damage in experimentally-induced cirrhosis in rats, Role of oxygen free radicals, Hepatology, 43(6), 1248-56.

- Niraj M.B ., Kinjal, C., Sharad, G., Prakash, P., Chirayu P., jyoti V. and Sarita, S. Gupta. (2011): Protective Effect of EnicostemmalittoraleBlumeMethanolic Extract on Gentamicin-Induced Nephrotoxicity in Rats. American Journal of Infectious Diseases.; 7 (4): 83-90.

- Nitha.B. and Janard h K. (2008):Aqueous-ethanolic extract of morel mushroom mycelium Morchellaesculenta, protects cisplatin and gentamicin induced nephrotoxicity in mice Original Research Article Food and Chemical Toxicology, Volume 46, Issue 9, September, Pages 3193-3199.

- Ohkawa, H., Ohahi, N. and Jadi, K. (1979): Assay for lipid peroxides in animal tissues by thiobarbituric acid reaction. Anal. Biochem; 95:351- 358.

- Paglia, D.F. and Valentaine, W.N. (1979): Studies on glutathione and glutathione characterization of erythrocytes glutathione peroxidase. J. Lab. Clin. Med., 70:158-169.

- Patton, C. J. and Crouch S.R. (1977): Enzymatic colorimetric method for determination of urea in serum.Anal. Chem., 49: 464-465.'

- Perez, R.M., Perez, J.A., Garcia, L.M. and Sossa, M.(1998):reno pharmacological activity of Solanumnigrumfruit.J Ethnopharmacol.,62:43-8.

- Polat. A., Parlakpinar, H., Tasdemir , S., Colak ,C., Vardi, N. and Ucar M. (2006): Protective role of aminoguanidineon gentamicin-induced acute renal failure in rats, ActaHistochem 108 pp. 365-371.

- Potawel, S.E., Sinha, S.D., Shroff, K.K., Dhalawat H.J, Boraste S.S .and Gandhi, S.P. (2008): Solanumnigrum Linn: A phytochemical Review. Pharmacology.3:140-63. 
- Pupsa ,R.S., Connie ,M.W. and A pril ,C.M.(1994): Mineral bioavailability in rats from intrinsically whole wheat flour of various phytate level .J. Agric .food .chem .,42(11):2531-35.

- Raju, K., Anbuganapathy, G., Gokulakrishnan, V., Rajkapoor, B., Jayakar, B. and Manian S.(2003): Effect of dried fruits of Solanumnigrum Linn against $\mathrm{CCL}_{4}$-induced hepatic damage in rats. Biol Pharm Bul.;26:1618-9.

- Rani, P. and Khullar, N.(2004): Antimicrobial evaluation of some medicinal plants for their anticentric potential against multidrug resistant. Phytother Res. 18:670-3.

- Reeves, P.G., Nielson, F.H. and Fahmy, G.C. (1993): Reports of the American Institute of Nutrition (AIN) Committee on Reformulation of the AIN 93 Rodent diet. J.

- Remuzzi,G ., Perico,N. Macla,M. and Ruggenenti ,P. (2005):The role of renin-angiotensin-aldosterone system in the progression of chronic kidney disease.Kidney Inter 68, S57- S65

- Romero, F., Pérez ,M., Chávez ,M., Parra, G., Durante, P. (2012): Effect of Uric Acid on Gentamicin and kInduced Nephrotoxicity in Rats-Role of Matrix Metalloproteinases 2 and 9.Basic and clinical pharmacology \& toxicology.;105(6):416-24.

- Safa, J., Argani, H., Bastani, B., Nezami, N., Ardebili, B.R., GhorbanihaghjoA,Kalagheichi H, Amirfirouzi A, Mesgari M, Rad JS, (2010): Protective effect of grape seed extract on gentamicin induced acute kidney injury . Iranian J of Kid Dise, 4, 285-291.

- Saleemi,A., Kashif,M., Khan ,M., Javed,L. and Khan, A. (2009):Pathological effects of gentamicin administered intramuscularly to day-old broiler chicks Original Rese ArtiExperi and ToxicolPatho, 61(5), 425-432.

- Shankar, S . and Arun Kumar, L. (2011): Nephroprotective evaluation of Rubusellipticus(smith) fruits extracts against cisplatin and gentamicin induced renal-toxicity in rats. Journal of Pharmacy Research. 4 (1): 285-287.

- Sharma ,R.K .(2011):Effect of Ethanolic and Aqueous Extracts of Bauhinia VariegataLinn.on Gentamicin-Induced Nephrotoxicity in Rats. Ind.JPharm.Ed. 45: 2:192-198. 
- Nephroprotective Effect of Aqueous Extract of Solanum Nigrum Linn leaves or seeds

- Singh,K., Ali ,N., Khan, M. and Ahirwar ,V .(2011): Effect ofSolanumnigrumon protein content of liver and kidney of albino rats. PharmacieGlobale (IJCP), 4 (08).

- Singleton ,V.I., and Rossi,J.A. (1965):Colorimetry of total phenolics with phosphomolybdic - phosphotungstic acid reagents .Am.J .Enolvitic 16:144-158.

- Sinha, K.A. (1972): Colorimetric assay of catalase enzyme. Anal.Biochem.; 47: 328-330.

- Snedecor, G.W. and Cochran, W.G. (1986): Statistical Methods. The 7th Edition, Iowa State University Press, Ames, USA, Page 90.

- Spitz, D.R. and Oberley, L.W. (1989): An assay for superoxide dismutase activity inmammaliantissuehomogenates. Anal.Biochem.; 179: 8-18.

- Stojiljkovic, N., Stoiljkovic, M., Randjelovic, P., Veljkovic, S. and Mihailovic, D. (2012): Cytoprotective effect of vitamin C againstgentamicininduced acute kidney injury in rats,Experimental and Toxicologic Pathology, 12(64), 69-74.

- Vale rise ,B.P. Alcindo ,J .,Cost, L., Carinne ,C. , Sandrine ,B., Denis ,S ., Olivier, L., Catherine ,C., Yvon,S • and filome ,C.(2006) :Impaired erythropoietin production in liver transplant recipients :the role of calcineurin inhibitors . liver transplantation ,12:1649-1654.

- Van-kats ，J., Methot,D., Paradis,P., Silversides,D. and Reudelhuber,T(2001):Use of biological peptide pump to study chronic peptide hormone action in transgenic mice :direct and indirect effects of angiotensin II on the heart .J. Biol.Chem ., 276:44012-44017.

- Walker, P.D., Barri, Y. and Shah S.V. (1999):Oxidant mechanisms in gentamicin nephrotoxicity, Ren. Fail. 21 (1999), pp. 433-442.

- Weichselbaum,T. F (1946): An accurate and rapid method for the determination of protein in small amount of blood serum and plasma . Am.JClin Path .,(16):40.

- Yarnell, E. and Abascal, K.(2007) Herbs for relieving chronic renal failure. Alternative and Complementary Therapies 13(1).18-23.

- ZietsE,R ., ZoutendijK,R and HoornE .J (2009):Fluid, electrolyte and acidbase disorders associated with antibiotic therapy. Nature Reviews Nephrology5, 193-202. 


\title{
التأثير الوقائي اللمستخلص المائي لأوراق وبذور عنب الدب (العرقد)
}

\section{وخليطهـا ضد السمية الكلوية المدثة بالجنتاهيسين في الفئران}

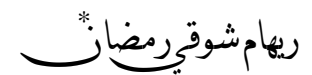

\author{
مايسة محمد الملالح \\ الملخص العربي
}

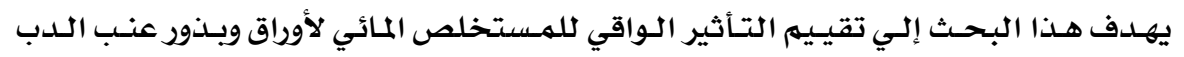

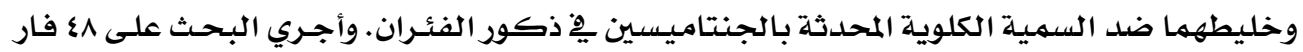

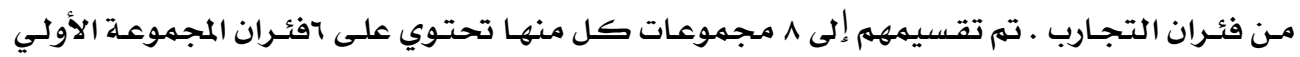

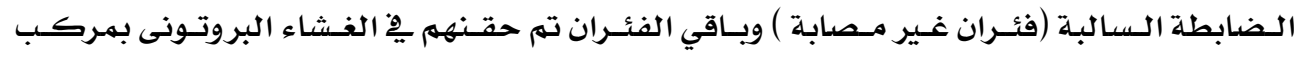

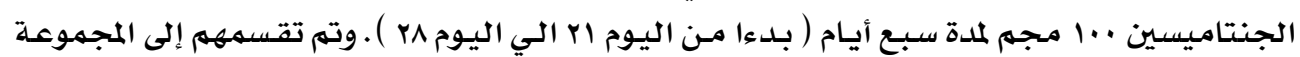

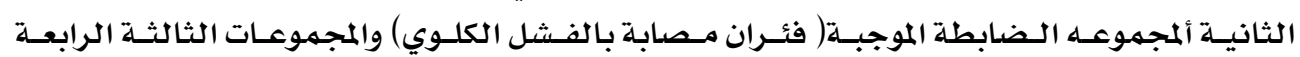

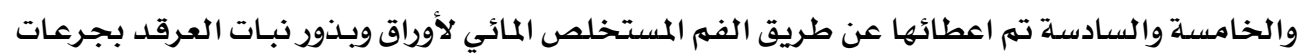

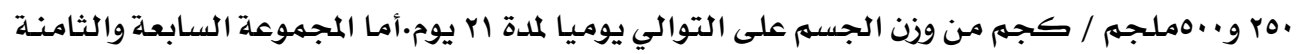

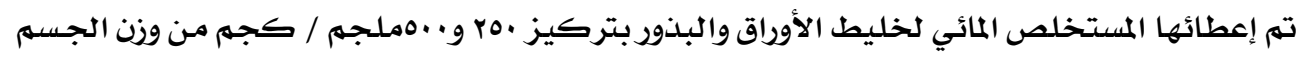

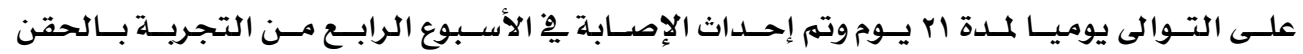

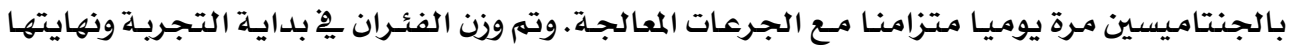

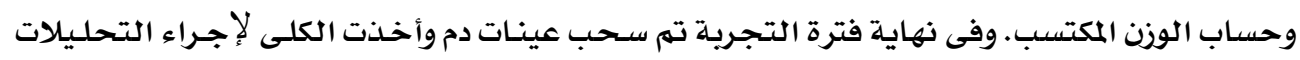

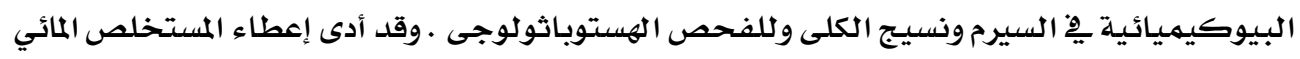

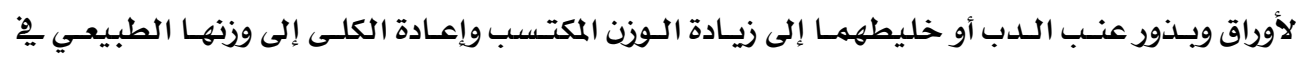

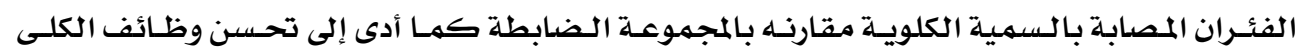

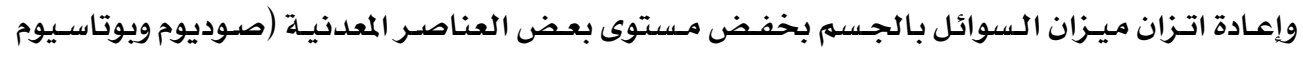

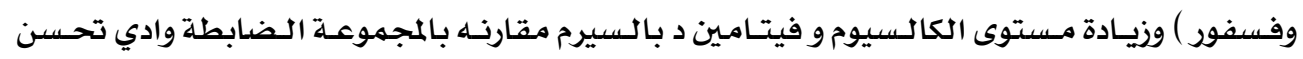

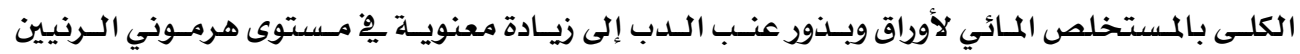

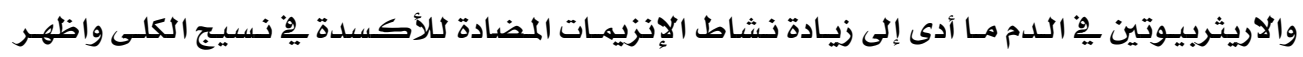

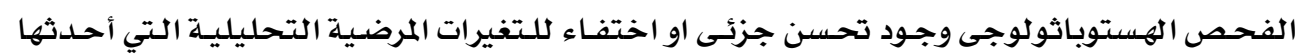

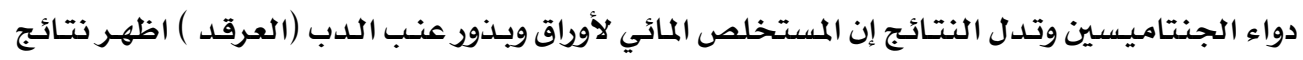

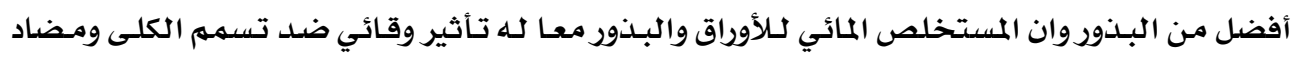

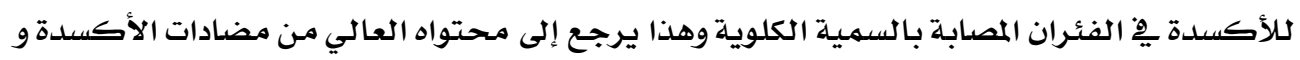

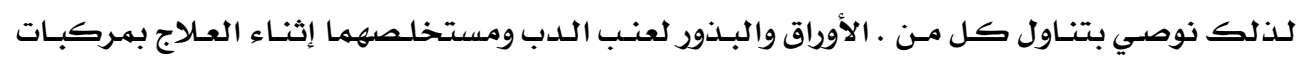
الجنتاميسن لتلايِ خطورته على خلايا الكلي.

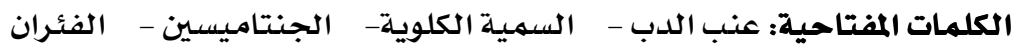

